\title{
Stulecie Kodeksu cywilnego szwajcarskiego
}

I. W dniu 1 stycznia 1912 roku wszedł w życie Kodeks cywilny szwajcarski (ZGB), zamykający poczet tzw. wielkich kodyfikacji cywilnych kontynentalnej Europy. Bogactwo doświadczeń ruchu kodyfikacyjnego naszego kręgu kulturowego pozwoliło redaktorom, a ściśle biorąc, jego twórcy, Eugenowi Huberowi, na stworzenie dzieła w pełni oryginalnego, łączącego w sposób doskonały wielowiekową tradycję prawną poszczególnych kantonów z wymogami współczesności, idee indywidualizmu z solidaryzmem społecznym, hasła liberalizmu z polityką interwencjonizmu, literę prawa z zasadami słuszności i etyki.

Długotrwały i trudny był proces narodzin kodyfikacji. Szwajcaria, niewielki terytorialnie, górzysty kraj położony w samym sercu Europy, na przecięciu jej głównych szlaków komunikacyjnych, był terenem nieustających walk między otaczającymi go z wszystkich stron potężnymi sąsiadami. Złożony z kilkudziesięciu niezależnych wspólnot rodowo-terytorialnych Związek był również miejscem wewnętrznych politycznych tarć, konfliktów zbrojnych, wojen domowych, powstań ludowych. Ich źródłem były nie tylko występujące tu różnice geograficzne, klimatyczne czy gospodarcze, ale i głębokie podziały społeczne, religijne, odrębności językowe, obyczajowe i kulturalne. Na tym podłożu kształtowały się trwałe fundamenty szwajcarskiego federalizmu, wyznaczające ramy ustrojowe długiej i wyboistej drogi do przyszłej kodyfikacji prawa prywatnego.

Tereny dzisiejszej Szwajcarii zamieszkane w starożytności przez plemiona celtyckie Helwetów, podbite przez legiony Cezara i włączone do rzymskiego Imperium, od wczesnego średniowiecza zajmowane przez szczepy germańskie Alemanów, Burgundów i Longobardów, weszły następnie w obręb monarchii Karolingów, a po jej rozpadzie, jako dział Lotariusza, znalazły się w orbicie politycznej I Rzeszy Niemieckiej.

Od schyłku średniowiecza przemiany ustrojowe w ramach Związku były wyznaczane dwoma charakterystycznymi czynnikami. Pierwszym z nich były, narastające wraz z rozwojem ekonomicznym kantonów miejskich i wzrostem 
ich aspiracji politycznych, tendencje do wewnętrznego jednoczenia sił poprzez zawiązywanie międzykantonalnych konfederacji (pierwszy tego typu związek powstał w 1291 r. ). Jednocześnie rosło poczucie odrębności kulturowej i niezawisłości politycznej od państw ościennych, zakorzenione szczególnie w przywiązanych do tradycji demokratyzmu tzw. komunach leśnych. To one stały się widownią potężnych ruchów oporu wolnych chłopów przeciw dominacji politycznej Habsburgów, o czym przypomina nam słynna legenda o Wilhemie Tellu.

Fenomenem urządzeń ustrojowych konfederacji stała się niespotykana, wywodząca się z ustroju rodowego w państwowości nowożytnej forma demokracji bezpośredniej, która z dzisiejszej perspektywy jest wyjaśniana przesłankami historycznymi - brakiem ośrodka, który mógłby się stać zalążkiem centralizacji władzy. Członkowie wolnych gmin Konfederacji, doskonale obeznani ze sztuką wojowania, nie byli skłonni do poddawania się jakimkolwiek autorytetom w życiu politycznym. Machiavelli pisał o nich, że są „,najlepiej uzbrojeni i najbardziej wolni", a Jean Bodin w swej teorii suwerenności władzy absolutnej właśnie na przykładzie Szwajcarii wykazywał różne „zboczenia” ustroju demokratycznego ${ }^{1}$.

Formalne uniezależnienie Konfederacji szwajcarskiej od Rzeszy w wyniku zakończenia tzw. „,wojny szwabskiej” w 1499 roku nie zmieniło jej struktury ustrojowej. Do dawnych konfliktów wewnętrznych doszły nowe, będące następstwem Reformacji i wojen religijnych między kantonami katolickimi i protestanckimi. W początkach XVI wieku, po przegranej bitwie z wojskami króla Franciszka I zakończonej traktatem pokojowym zawartym w 1516 roku we Fryburgu, Francja uzyskała poważne korzyści od pokonanej Konfederacji w postaci gwarancji stałego dopływu szwajcarskich najemników.

W wyniku wojny trzydziestoletniej Konfederacja uzyskała wprawdzie formalnie niezależność polityczną, ale Sejm Związkowy nie doprowadził do uzgodnienia wspólnej polityki zagranicznej i obronnej. Utrzymała się więc polityczna dominacja Francji. Nie doszło też do przełamania skostniałych struktur ustrojowych, opierających się na autonomii wspólnot lokalnych, ani do przezwyciężenia wewnętrznych antagonizmów społecznych. W kantonach miejskich konflikty te występowały między patrycjatem a średnimi warstwami mieszczaństwa, zaś w kantonach wiejskich wyrażały się oporem wolnych chłopów przeciw zdominowaniu struktur wspólnoty, tj. nawiązujących do tradycji demokracji wojennej zgromadzeń gminnych (Landesgemeinde) przez przedstawicieli najznaczniejszych rodów. Urządzenia ustrojowe konfederacji szwajcarskiej trwały w niezmienionym kształcie aż do epoki napoleońskiej.

Wydarzenia rewolucji francuskiej spowodowały w kantonach szwajcarskich wzrost nastrojów rewolucyjnych i aktywizację środowisk wiążących

${ }^{1}$ E. Bucher, Historische Grundlegung: Die Entwicklung der Schweiz zu einem politischen System, w: Das politische System der Schweiz, München1971, s. 17. Por. moje omówienie w P i P, 1973, z. 8-9, s. 228 n. 
nadzieje na radykalne zmiany polityczne. Rozwiały się one w czasach Dyrektoriatu, kiedy niezwykle ważne ze względów strategicznych terytoria Konfederacji zostały wykorzystane w planach militarnej inwazji wojsk napoleońskich. Jej finałem było utworzenie w 1798 roku w Aarau, z połączenia 23 kantonów, państwa unitarnego pn. Jednej i Niepodzielnej Republiki Helweckiej. Ten przejściowy twór, narzucony wbrew silnie zakorzenionej tradycji politycznej suwerenności, trwał tylko do roku 1803, kiedy Napoleon droga „mediacji”, na mocy tzw. aktu pośredniczącego (Vermittlungsakt), utworzył z 19 kantonów luźny Związek o charakterze konfederacji, jako jedno z wielu terytoriów wasalnych znajdujących się w orbicie Grand Empire'u.

Po upadku Napoleona losy szwajcarskich terytoriów rozstrzygały się na kongresie wiedeńskim - już pod polityczną dominacją metternichowskiej Austrii. Powołany do życia w 1815 roku Związek Szwajcarski stanowił konfederację złożoną z 22 kantonów. Organem wspólnym był Sejm Związkowy, w którym każdy kanton miał jeden głos. Poszczególnym kantonom przyznano rozległe kompetencje, m.in. ustawodawcze (z wyjątkiem zawierania umów międzynarodowych). Pogłębiał się również partykularyzm ekonomiczny, zwłaszcza skutkiem piętrzenia się barier celnych między kantonami, utrudniających kontakty handlowe.

Dopiero w wyniku wojny domowej u schyłku 1847 roku nastapiły radykalne zmiany ustrojowe. Przyjęta w głosowaniu powszechnym konstytucja 1848 roku, o charakterze kompromisu między tendencjami centralizacyjnymi a dotychczasowym systemem luźnego związku państw, zmierzała w kierunku nadania Szwajcarii ustroju państwa związkowego. Przyznawała szerokie kompetecje władzom centralnym, ale w gestii kantonów pozostawiono ustawodawstwo i sądownictwo. Utrzymano więc istniejący partykularyzm prawny. Przełom $\mathrm{w}$ tej dziedzinie zapoczątkowała obowiązująca do dziś Związkowa Konstytucja Konfederacji Szwajcarskiej z 1874 roku (Bundesverfassung des Schweizerischen Eidgenossenschaft, Constitution fédérale de la Confédération suisse).

II. Partykularyzm prawny Szwajcarii sięgał czasów, gdy tereny pierwotnie zamieszkane przez górskie plemiona Retów i celtyckich Helwetów, podbite przez legiony Cezara i włączone w obręb cywilizacji rzymskiej, były od IV wieku zajmowane przez szczepy germańskie Alemanów, Burgundów i Longobardów, którzy posługiwali się - zgodnie z zasadą osobowości prawa - własnymi spisami prawa zwyczajowego. Najwcześniejszy z nich to południowogermańska Lex Alemannorum, a następnie wydana przez króla Burgundów Lex Gundobada oraz zbiór praw dla ludności rzymskiej Lex Romana Burgundionum. Natomiast Longobardowie zajęli Italię jako zdobywcy, narzucając ludności miejscowej własne prawa. Najwcześniejszym był Edykt Rothara z VII wieku, pomnik prawa o ściśle germańskim charakterze, nieuznający na zajętych 
terytoriach mocy prawa rzymskiego Natomiast nieco poźniejszy Edykt Liutpranda dopuszczał już stosowanie w praktyce prawa rzymskiego na równi z prawem longobardzkim.

Warto wyjaśnić tu problem recepcji prawa rzymskiego w życiu prawnym kantonów szwajcarskich późnego średniowiecza, który w XIX stuleciu stanie się punktem ostrych sporów w łonie szkoły historycznej między germanistami i romanistami, a i dziś budzący zainteresowanie badaczy. W ówczesnych polemikach uczeni obozu germanistów głosili tezę, że wspólnoty szwajcarskie, w imię utrzymania swej niezawisłości politycznej wobec potężnych sąsiadów, broniły się również przed napływem obcych praw. Stąd też prawo rzymskie nie zdołało się na tych terenach zakorzenić. Przykładem służyć miała często przywoływana w literaturze na dowód niechętnego stosunku do ,praw uczonych” opowieść o tym, jak ongiś ławnicy sądowi z Frauenfeld przerwali w czasie rozprawy sądowej wywody uczonego doktora praw z Konstancji słowami: „My nie pytamy o żadnych bartolistów ani baldystów i innych doktorów, bo mamy własne prawa. .."2

Przypowieść ta, niezależnie od kwestii jej autentyczności, służyła badaczom do uzasadniania przeciwstawnych sobie wniosków. W dzisiejszej historiografii prawniczej dominuje pogląd, że w późnym średniowieczu w kantonach miejskich miał miejsce - podobnie jak w Rzeszy doby tzw. wczesnej recepcji - proces intensywnego przenikania obu ,praw uczonych”. Dokonywał się on w głównej mierze poprzez kształconych na prawie rzymskim w Bolonii studentów, którzy po powrocie do swych krajów obejmowali funkcje w urzędach miejskich, sądownictwie, adwokaturze, notariacie czy w służbie dyplomatycznej ${ }^{3}$. Proces ten zamarł dopiero w wieku XVI, wraz z formalnym uniezależnieniem się Konfederacji od Rzeszy Niemieckiej po tzw. „wojnie szwabskiej”. Nastąpiło wtedy oderwanie praktyki wymiaru sprawiedliwości od dorobku judykatury Sądu Kameralnego, zerwały się też więzi naukowe $\mathrm{z}$ uniwersytetami niemieckimi.

Wraz z utrata przez miasta szwajcarskie dotychczasowej pozycji centralnych ośrodków handlowych Europy i nawrotem gmin wiejskich do tradycyjnych metod gospodarowania pogłębiała się stagnacja życia prawnego i partykularyzm źródeł prawa prywatnego. Wprawdzie dążenia do lepszej znajomości prawa i bezpieczeństwa obrotu gospodarczego prowadziły do sporządzania

${ }^{2}$ C. Schott, Wir Eidgenossen fragen nicht nach Bartele und Baldene, w: Gerichtslauben=Vorträge. Freiburger Festkolloquium zum fünfundsiebzigsten Geburtstag von Hans Thieme. Sigmarinen 1983, s. 17 n. Autor dowodzi, że prawo rzymskie w Szwajcarii aż do XVI w. cieszyło się równym co w Rzeszy powodzeniem. Dopiero odcięcie sądownictwa od judykatury Sądu Kameralnego, izolacjonizm miast i brak napływu kadr prawniczych spowodował odwrót ku prawu rodzimemu (por. moje omówienie artykułu w CPH XXVIII, 2, 1986 s. 206 n.

${ }^{3}$ Nabyta na studiach znajomość prawa kanonicznego dawała z kolei możliwość obejmowania stanowisk w sądach duchownych biskupstw Konstancji, Bazylei i Chur. H. Schlosser, Grundzüge der Neueren Privatrechtsgeschichte, wyd. VII, Heidelberg 1993, s. 47 n. 
różnego rodzaju zbiorów praw lokalnych, spisów prawa ziemskiego, statutów miejskich, ksiagg sądowych itp., ale nadal źródłami prawa w sądownictwie pozostawały niepisane zwyczaje prawne. Ten okres życia prawnego nazywano w literaturze fazą "szwajcarskiego wulgaryzmu” (eidgenossische Vulgarismus), który trwał do czasów wielkiego przełomu, tj. epoki Oświecenia.

W drugiej połowie XVIII wieku nastapiło niezwykłe ożywienie życia umysłowego pod wpływem płynących z ościennych krajów prądów ideowych Wieku Świateł. W kręgach inteligencji mieszczańskiej powstawały programy unowocześnienia ustroju politycznego i niwelowania głębokich podziałów społecznych w duchu demokratyzmu, inspirowane w znacznej mierze dziełami Jana Jakuba Rousseau, który, mimo zamknięcia przed nim bram rodzimej Genewy, nie przestawał podejmować w swych traktatach politycznych wewnętrznych problemów kraju.

Wśród elit intelektualnych szwajcarskiego Oświecenia prym wiedli prawnicy - szczególnie krąg badaczy zachodnioeuropejskiej filozofii nowożytnego prawa natury. Tworzyli oni odrębny kierunek naukowy zwany „Szkołą romańską" prawa natury, której zadaniem było m.in. rozpowszechnianie wśród postępowej inteligencji dorobku tego nurtu ideologicznego. Szkoła odegrała znaczącą rolę nie tylko w samej Szwajcarii romańskiej, ale zapisała się trwale w dziejach europejskiej myśli prawniczej ${ }^{4}$.

Wśród założycieli Szkoły należy wymienić przede wszystkim Jeana Barbeyraca (1674-1744), pochodzącego z rodziny francuskich hugenotów - wypędzonych z kraju po odwołaniu przez Ludwika XIV edyktu nantejskiego profesora prawa Akademii w Lozannie (utworzenie tam przezeń w 1711 r. katedry prawa natury uważane jest za początek działalności Szkoły). Zasłynął on jako thumacz oraz komentator dzieł Hugona Grocjusza i Samuela Pufendorfa.

Drugim z założycieli był Jean-Jacques Burlamaqui (1694-1748), pochodzący z rodziny protestantów włoskich, profesor prawa natury i prawa cywilnego Akademii w Genewie ${ }^{5}$. Uznawany za wiernego ucznia Pufendorfa, wydawca i autor przekładów dzieł Mistrza, interesował się także programem filozofów niemieckich z okresu młodszego, tzw. „względnego” prawa natury, kiedy ten nurt filozoficzny zszedł z wyżyn uniwersalnego systemu absolutnych prawd, by przenikać bezpośrednio do ustawodawstwa i praktyki sądowej ${ }^{6}$. Burlamaqui był zafascynowany dziełami Christiana Thomasiusa, które również popularyzował w kręgach jurysprudencji francuskojęzycznej.

${ }^{4}$ Ogólną charakterystykę programu Szkoły i sylwetek jej przedstawicieli daje A. Dufour, Le mariage dans l'école romande du droit naturel au XVIIIe siècle, Genève 1976, s. 1-35; spod jego pióra wyszła wcześniej wartościowa monografia Le mariage dans l'ècole allemande du droit naturel moderne, au XVIII siècle, Paris 1972 (por. moje omówienie w: CPH, 1973 t. XXV, z. 1 s. 194 n.).

5 J. J. Burlamaqui prowadził wykład prawa natury według dzieła Pufendorfa De iure naturae et gentium, libri octo, a prawa cywilnego - na podstawie Instytucji Justyniana.

${ }^{6}$ Szerzej o tym K. Sójka-Zielińska, Wielkie kodyfikacje cywilne. Historia i wspótczesność, LIBER Warszawa 2009, s. $52 \mathrm{n}$. 
Szczególne zainteresowania filozofami niemieckiej szkoły prawa natury wykazywał przedstawiciel młodszej generacji adeptów Szkoły romańskiej Emer de Vattel (1714-1767) z Neuchâtel, studiujący w Genewie u J.J. Burlamaquiego, wybitny znawca, ale i krytyczny komentator twórczości Chrystiana Wolffa ${ }^{7}$.

Szkoła romańska odegrała znaczącą rolę nie tylko w dziedzinie filozofii prawa, gdy w jej ramach podejmowano dyskurs o fundamentalnych kwestiach relacji między prawem stanowionym a prawem moralnym, czy też o przyrodzonych każdej jednostce niezbywalnych i nieodbieralnych prawach naturalnych. W literaturze wykazuje się również jej wpływ na niektóre regulacje ustawowe w późniejszych kantonalnych kodyfikacjach cywilnych, zwłaszcza $\mathrm{w}$ dziedzinie prawa osobowego ${ }^{8}$.

W formułowanym przez ideologów Oświecenia szwajcarskiego programie reformy prawa, ściśle związanym z przeobrażeniami ekonomicznymi czasów rewolucji przemysłowej, ważne miejsce zajmowały postulaty unowocześnienia i ujednolicenia prawnych regulacji obrotu gospodarczego. Znane tu teoretyczne traktaty o sztuce prawodawstwa, a przede wszystkim płynące z doświadczeń systemu oświeconego absolutyzmu monarchii Habsburgów prace nad kodyfikacją prawa, były impulsem do rysowania planów nowoczesnego ustawodawstwa, tj. tworzenia prawa mającego charakter iuris certi, powszechnie zrozumiałego, niebudzącego wątpliwości interpretacyjnych, ujętego w naukowo opracowany system.

Rysowały się trzy drogi zmierzające do unifikowania prawa prywatnego w ramach poszczególnych kantonów. Pierwsza z nich wiodła przez ujednolicanie instytucji prawa prywatnego w orzecznictwie sądowym i stopniowe uchylanie w praktyce sądowej praw partykularnych. Drugą możliwość unifikacji widziano poprzez wydawanie ustaw szczególnych, regulujących najważniejsze instytucje prawa prywatnego. Wreszcie trzecia droga to opracowanie kantonalnych kodeksów prawa prywatnego, zgodnie z zasadami opracowanymi w dziełach poświęconych teorii nowoczesnego ustawodawstwa, a także doświadczeniami prac kodyfikacyjnych w Prusach i Austrii. W następnym stuleciu ten właśnie kierunek obierze większość krajów związkowych, co doprowadzi do powstania w początkach XX wieku ogólnoszwajcarskiej kodyfikacji prawa prywatnego.

\footnotetext{
${ }^{7}$ Warto tu wspomnieć o jego związkach z Polską podczas służby dyplomatycznej na dworze Augusta II w Dreźnie, a następnie objęcie stanowiska osobistego wysłannika króla polskiego w Bernie.

${ }^{8}$ Por. wspomnianą w przyp. 4 monografię A. Dufoura o badaniach nad prawem małżeńskim w Szkole romańskiej prawa natury. Podkreślał tam nie tylko rolę Szkoły w dziejach europejskiej myśli prawniczej, ale i jej funkcję mediacyjną - jak pisze - „między zwyczajami lokalnymi a recepcją najważniejszej kodyfikacji epoki prawa natury, Kodeksu Napoleona” (tamże, s. 35).
} 
III. Po krótkim epizodzie narzuconej w czasie inwazji napoleońskiej wbrew tradycji regionalizmu - konstytucji unitarnej „Republiki Helweckiej” z 1798 roku, zapowiadającej wprowadzenie jednolitego kodeksu cywilnego dla całego państwa (do tego czasu obowiązywać miały prawa dotychczasowe), już wkrótce tzw. „Akt mediacji” z 1803 roku przywracał system ustrojowy konfederacji oraz samodzielność kantonów, m.in. w zakresie ustawodawstwa cywilnego.

Poza terytoriami wcielonymi do Francji, na których obowiązywał Kodeks Napoleona, poszczególne kantony szwajcarskie podejmowały od lat 20. XIX wieku intensywne prace kodyfikacyjne, których efektem było zredagowanie przeszło dwudziestu lokalnych kodeksów cywilnych.

W literaturze przyjęto dzielić kodeksy kantonalne na następujące grupy ${ }^{9}$ :

1) kodeksów wzorowanych na francuskim Code civil,

2) kodeksów opierających się na austriackim ABGB,

3) kodeksów, dla których wzorem był kodeks cywilny Zurychu.

Do grupy pierwszej zaliczano kodeksy powstałe w kantonach południowo-zachodnich: Vaud (1819), Tessin (1837), Wallis (1853/54) i Neuchâtel (1854/55).

Do grupy drugiej, tzw. berneńskiej, obejmującej kantony środkowe, zalicza się m.in. kodeksy Berna (1824-30), Lucerny (1831-39), Solury (1841-47), Argowii (1847-55) i Turgowii (1858-60).

Grupę trzecią, zwaną zurychską, tworzyły m.in. kodeksy cywilne kantonu Gryzonii (1862), Schaffhausen (1864/65) i Glarus (1869/74) wzorowane na kodeksie cywilnym Zurychu (1853-55), dziele wybitnego uczonego szkoły historycznej Johanna Caspara Bluntschliego.

Powstanie kodeksu Bluntschliego wiązało się z działalnością ważnego ośrodka naukowego w Zurychu, jakim był już od lat 20. XIX wieku Instytut Polityczny (Politisches Institut), ówczesne centrum badań nad prawoznawstwem, pozostające w kręgu wpływów niemieckiej szkoły historycznej. Do czołowych reprezentantów tego kierunku w Instytucie zaliczano F.L. Kellera (1799-1860), romanistę o poglądach liberalnych, nazywanego, nie bez podstaw, ,założycielem nowoczesnej szwajcarskiej nauki prawa"10. Po studiach w Berlinie i Getyndze Keller wrócił do Zurychu, gdzie od 1824 roku objął w Instytucie stanowisko wykładowcy prawa rzymskiego. Wychodził z założe-

\footnotetext{
${ }^{9}$ Podział ten znalazł się po raz pierwszy w fundamentalnym dziele twórcy kodeksu szwajcarskiego Eugena Hubera System und Geschichte des Schweizerischen Privatrechtes. IV, Basel 1893, s. 185 n. Szczegółową charakterystykę kodeksów kantonów romańskich daje E. Holthöfer: Kodifikation in den romanischen Kantonen, w: Handbuch der Quellen und Literatur der neueren europäischen Privatrechtsgeschichte, hrsg. H. Coing, Band III, 2, München 1982, s. 1859-1924. Tamże też opracowanie kodeksów kantonów zaliczanych do grupy berneńskiej i zurychskiej pióra Barbary Dölemeyer: Kodifikation in den deutschsprachigen Kantonen (s. 1925-1960).

${ }^{10}$ P. Caroni, Die Schweizer Romanistik im 19. Jahrhundert, „Zeitschrift für Neuere Rechtsgeschichte", 1994, Nr 3, s. 264.
} 
nia, że choć w Szwajcarii nie nastąpiła oficjalna recepcja prawa rzymskiego, znajomość romanistyki powinna stanowić - jeszcze w większym stopniu niż w krajach niemieckich - jedną z podstaw studiów prawniczych. Nie chodziło tu o rodzaj ,gimnastyki intelektualnej” ani o dogmatyczny rozbiór dorobku jurysprudencji rzymskiej, ale o spojrzenie współczesnego prawnika z perspektywy historycznej na określone rozwiązania prawne i sięganie do nich jako do rationis scriptae ${ }^{11}$. Myślą przewodnią nowego systemu nauczania było unaukowienie studiów prawa rodzimego poprzez ich nasycanie treściami czerpany$\mathrm{mi}$ z dorobku recypowanego prawa rzymskiego w postaci stosowanego w krajach niemieckich gemeines Rechts. F.L. Keller podjął także prace nad skodyfikowaniem kantonalnego prawa prywatnego.

W tych czasach w Instytucie Politycznym rozpoczynał studia Johann Caspar Bluntschli (1808-1881), liberalny konserwatysta, pochodzący ze starej rodziny zurychskich fabrykantów. Od 1827 roku pogłębiał on studia prawnicze, historyczne i filozoficzne w Berlinie w kręgu szkoły historycznej F.K. Savigny'ego, pod kierunkiem Karola Eichhorna. Doktoryzowal się z prawa rzymskiego w Bonn. Po powrocie do kraju, po kilku latach praktyki w notariacie i sądownictwie, został od 1833 roku profesorem prawa rzymskiego, prawa cywilnego niemieckiego i historii prawa na nowo powstałym uniwersytecie w Zurychu.

Były to lata pogłębiającego się rozdźwięku między dwoma odłamami szkoły historycznej: romanistami, prowadzącymi badania nad klasycznym prawem rzymskim i jego przemianami w dobie recepcji, oraz germanistami, zwróconymi ku dziejom prawa rodzimego, tj. germańskich praw szczepowych i prawa ludowego, Volksrecht. Konflikt ten doprowadził u schyłku lat dwudziestych XIX wieku do rozłamu dokonanego przez germanistów ${ }^{12}$. Bluntschli skłaniał się ku zwolennikom tego kierunku, a nawet opracował program badań nad historią prawa szwajcarskiego, akcentując znaczenie metodologii i zdobyczy naukowych szkoły historycznej w badaniach nad prawem. W powstałym ówcześnie dziele, Staats- und Rechtsgeschichte der Stadt und Landschaft Zürich, zadedykowanym zarówno Savigny'emu, jak i przywódcy germanistów $\mathrm{K}$. Eichhornowi, sięgał w badaniach nad dziejami ustroju i prawa rodzimego do rdzennie germańskich korzeni, tj. praw zwyczajowych, w których najsłabiej zaznaczały się wpływy romanistyczne. To wczesne dzieło Bluntschliego miało

${ }^{11}$ Ideą nowego systemu nauczania było unaukowienie studiów prawa rodzimego poprzez ich nasycanie treściami czerpanymi z dorobku prawa „uczonego” (gelehrten Rechts). W literaturze przyjęto nazywać to metodą nauczania prawa rzymskiego nach schweizerischen Art.

${ }^{12}$ Znakiem zerwania było powołanie przez germanistów własnego czasopisma ,Zeitschrift für deutsches Recht" pod hasłami poszukiwania w badaniach historycznych tradycji prawa narodowego w obronie przed - jak mówiono - ,stronniczym romanizmem”. O tym szerzej K. Sójka-Zielińska, $W$ sprawie oceny romanistycznego i germanistycznego kierunku szkoły historycznej w niemieckiej nauce prawa I połowy XIX wieku. CPH, XI, 2 1959, s. 129 n. 
doniosłe znaczenie dla ugruntowania się w prawoznawstwie, zwłaszcza w cywilistyce, metod badawczych szkoły historycznej.

W krajach niemieckich wśród ówczesnych germanistów o orientacji narodowo-liberalnej wzrastało zainteresowanie tymi dziedzinami prawa, które wiązały się z potrzebami rozwoju przemyslu i obrotu towarowego, jak prawo handlowe, wekslowe, przemysłowe itp., a które ówcześnie leżały poza kręgiem zainteresowań romanistów. Jednocześnie, wbrew negatywnemu stanowisku Savigny'ego germaniści uznawali potrzebę ich ujęcia w ramy ustawodawstwa szczególnego, przy wykorzystaniu aparatu pojęciowego pandektystyki ${ }^{13}$.

W Szwajcarii do zwolenników inicjatyw skodyfikowania prawa handlowego w ramach kodeksu cywilnego należał J.C. Bluntschli. W roku 1840 podjął się on kontynuowania zaczętych przez K.F. Kellera prac nad unifikacją źródeł lokalnego prawa prywatnego. Po ukończeniu pod jego przewodnictwem prac komisji nad poszczególnymi częściami projektu kodeks został w latach 1854/55 uchwalony pn. Privatrechtliches Gesetzbuch für den Kanton Zürich (PGZ).

Kodeks Zurychu za podstawę układu przyjął grosso modo systematykę opracowaną w ówczesnej nauce pandektów. Składał się z pięciu ksiąg:

1) prawa osobowego,

2) familijnego,

3) rzeczowego,

4) zobowiązań,

5) spadkowego.

Natomiast nie zawierał części ogólnej, a tylko krótkie wprowadzenie obejmujące $\mathrm{w}$ siedmiu paragrafach przepisy prawa prywatnego międzynarodowego i międzykantonalnego. Był pierwszym kodeksem jednolitym, który w księdze o zobowiązaniach pomieścił również przepisy prawa handlowego, a większość unormowań dotyczących kupców rozciągał na osoby niebędące kupcami ${ }^{14}$. Rozwiązania te staną się - o czym będzie szerzej mowa - wzorcem dla redaktorów szwajcarskiego kodeksu zobowiązań z 1881 roku.

Kodeks Zurychu jest oceniany w literaturze jako dzieło modelowe, stanowiące udaną syntezę rodzimej tradycji prawnej z nowoczesnymi regulacjami różnych dziedzin prawa prywatnego ${ }^{15}$. Do niektórych jego rozwiązań sięgali redaktorzy projektu ogólnoniemieckiego prawa zobowiązań z 1866 roku (tzw.

${ }^{13}$ Twórcą nauki prawa handlowego jako odrębnej dziedziny prawoznawstwa i autorem fundamentalnego podręcznika był romanista Levin Goldschmidt z Berlina. H. Schlosser, Grundzüge, o. c. s. $137 \mathrm{n}$.

${ }^{14} \mathrm{Z}$ kolei w księdze I o prawie osobowym znalazły się przepisy prawa o stowarzyszeniach, spółkach i korporacjach. B. Dölemeyer, Handbuch III, 2, s. 1944.

${ }^{15} \mathrm{Z}$ tego też powodu Bluntschli spośród ówczesnych kodeksów cywilnych najwyżej cenił Code civil, nazywając kodyfikację napoleońską ,,pierwszym na światową skalę rozwiązaniem łączącym w doskonały sposób prawo rzymskie z tradycjami prawa rodzimego, a jednocześnie odpowiadającym wymogom współczesności”. E. Huber, System, IV, s. 186. 
projekt drezdeński). Dzieło Bluntschliego odegrać też miało w przyszłości znaczącą rolę w pracach nad ogólnoszwajcarskim kodeksem cywilnym.

IV. W połowie XIX wieku partykularyzm prawny w dziedzinie prawa prywatnego stawał się w obliczu burzliwych przemian gospodarczych, tempa industrializacji i skali kontaktów handlowych między kantonami rażącym anachronizmem. Silnie też oddziaływały płynące z krajów niemieckich postulaty ogólnoniemieckiej kodyfikacji prawa, które w dobie Wiosny Ludów znajdą się wśród sztandarowych haseł zjednoczenia politycznego i umocnienia jedności narodu niemieckiego ${ }^{16}$.

Dążenia do unifikacji prawnej zarówno w krajach Związku Niemieckiego jak i w kantonach szwajcarskich przebiegały bardzo podobnymi drogami. Wiodły one od planów wspólnego ustawodawstwa handlowego, poprzez unifikację prawa zobowiązań, aż po całościową kodyfikację prawa cywilnego.

W Związku Niemieckim pierwszym ważnym krokiem w kierunku unifikacji obrotu handlowego był powołany z inicjatywy Prus w 1834 roku Związek Celny (Zollverein), obejmujący kilkanaście krajów sąsiadujących z monarchią Hohenzollernów, a następnie uchwalona w czasie rewolucji 1848 roku przez Zgromadzenie Frankfurckie ordynacja wekslowa, Allgemeine Deutsche Wechselordnung (ADWO) ${ }^{17}$.

Prace nad ujednoliceniem całego prawa handlowego podjęto dopiero w roku 1857. Powołana wówczas do życia z inicjatywy Prus w Norymberdze komisja opracowała w 1861 roku Allgemeines Deutsches Handelsgesetzbuch (ADHGB), który został przyjęty następnie przez prawie wszystkie kraje Związku Niemieckiego. Wzorowany częściowo na francuskim Code de commerce z 1807 roku, kodeks z 1861 roku, znacznie go przewyższający zarówno objętością jak i poziomem techniki legislacyjnej, był uznawany ówcześnie za modelową kodyfikację prawa handlowego. Redaktorzy czerpali tu z dzieł twórcy nauki nowoczesnego prawa handlowego, Lewina Goldschmidta (1829-1897). Kodeks przyjmował jako podstawę kryterium obiektywne, czyli uznanie pewnych typów czynności prawnych za czynności handlowe, a osoby je wykonujące - za kupców. Po zjednoczeniu Niemiec kodeks handlowy z 1861 roku wprowadzono w 1871 roku jako ustawę Rzeszy obowiązującą do 1 I 1900 roku, tj. wejścia w życie nowego kodeksu handlowego Handelsgesetzbuch (HGB) z 1898 roku.

${ }^{16} \mathrm{~W}$ projekcie konstytucji z marca 1849 r. (Paulskirche=Verfassung) zapisano, że do kompetencji Rzeszy należeć będzie wydanie m.in. kodeksu cywilnego, handlowego i wekslowego. W parlamentcie frankfurckim doszło tylko do uchwalenia ogólnoniemieckiej ordynacji wekslowej (udział w pracach brał F.K. Savigny!), którą wprowadzono w niektórych państwach związkowych, jako prawo partykularne. K. Sójka-Zielińska, Wielkie kodyfikacje, s. 289 n.

${ }^{17}$ Ordynacja wekslowa wszędzie weszła wprawdzie w życie (z wyjątkiem Austrii), ale niebawem zakwestionowano jej konstytucyjne podstawy. H. Schlosser, Grundzüge, s. 144. 
Mimo ujednolicenia prawa handlowego zróżnicowanie państw Związku Niemieckiego w dziedzinie prawa prywatnego nadal stanowiło najważniejszą przeszkodę w rozwoju życia gospodarczego. Z inicjatywy dziesięciu krajów związkowych (m.in. Bawarii, Wirtembergii, Saksonii) powołano w Dreźnie komisję do opracowania ogólnoniemieckiego prawa zobowiązań ${ }^{18}$. W roku 1866 komisja przedstawiła Sejmowi Związkowemu projekt ogólnoniemieckiego prawa zobowiązań (tzw. projekt drezdeński). Jednak wybuch wojny Prus z Austrią spowodował zaprzestanie prac, a po zjednoczeniu Niemiec i stosownej poprawce w roku 1873 do konstytucji II Rzeszy (Lex Lasker) sprawa unifikacji prawa zobowiązań znalazła się w planach opracowania ogólnoniemieckiego kodeksu cywilnego. Projekt drezdeński został natomiast wykorzystany w pracach nad unifikacją szwajcarskiego prawa zobowiązań.

W Szwajcarii pierwsze inicjatywy unifikacyjne wysuwano już w czasie prac nad konstytucją 1848 roku, ale napotykały one sprzeciw ze strony niektórych konserwatywnych kantonów obawiających się ograniczenia politycznej niezawisłości. Wprawdzie nie zdołano wtedy przeforsować generalnej zasady wolności handlowej i przemysłowej, ale w ramach istniejących zapisów konstytucyjnych wykorzystano możliwość zniesienia barier celnych, ujednolicenia systemu monetarnego, miar i wag, a na miejsce przywilejów korporacyjnych wprowadzenia zasady wolnej konkurencji. Potwierdzano też występujące zresztą w większości kantonalnych kodeksów cywilnych - zasady powszechności praw cywilnych i równości wobec prawa ${ }^{19}$.

Pierwszym krokiem Konfederacji szwajcarskiej w kierunku unifikacji prawa - podobnie jak w Związku Niemieckim - było opracowanie w 1856 roku prawa wekslowego wraz z propozycją jego wprowadzenia drogą porozumień międzykantonalnych, tzw. „konkordatów”. Jednak z tej możliwości skorzystało tylko kilka kantonów ${ }^{20}$. Tymczasem tempo rewolucyjnych przemian w dziedzinie środków transportu i łączności zmuszało do podejmowania radykalnych zmian ustawodawczych. W niemieckojęzycznych kantonach miejskich aktywizowały się organizacje gospodarcze, liczne stowarzyszenia przemysłowo-handlowe, które domagały się pilnego ujednolicenia zasad obrotu handlowego w skali całego państwa. Kierowano petycje do Rady Związku, by przynajmniej drogą konkordatową umożliwić zawieranie unii handlowych jak największej liczbie krajów związkowych. Postulaty te znalazły też wsparcie ze strony gremiów prawniczych, zwłaszcza w powstałym w 1861 roku szwajcar-

${ }^{18} \mathrm{O}$ możliwościach tego rodzaju przedsięwzięcia świadczyło opracowanie w 1863 r. saskiego kodeksu cywilnego (Bürgerliches Gesetzbuch für das Königreich Sachsen). Nie chciano natomiast poruszać sprawy unifikacji prawa rodzinnego, czy spadkowego, gdyż uważano to za zbyt daleko idące wkraczanie ustawodawcy w sferę praw i zwyczajów miejscowych.

${ }^{19}$ P. Caroni, Rechtseinheit. Drei historische Studien zu Art. 64 BV, Basel u. Frankfurt am Main, 1986, s. 12 n.

${ }^{20}$ Berno, Lucerna, Solura, Bazylea i Schaffhausen. 
skim Związku Prawników (Juristenverein), który stanie się główną siłą patronującą idei unifikacji prawa. Niemały wpływ wywierały też płynące z Niemiec doświadczenia prac wspomnianej komisji norymberskiej, które doprowadziły w 1861 roku do uchwalenia ogólnoniemieckiego kodeksu handlowego.

Pierwsze inicjatywy ujednolicenia prawa handlowego powstawały w kręgach stowarzyszeń gospodarczych i towarzystw prawniczych działających w uprzemysłowionych regionach niemieckojęzycznych. Najwcześniej podjęto prace legislacyjne w Bernie. Ich wynikiem był opracowany w roku 1864 przez berneńskiego profesora Waltera Munzingera (1830-1873) projekt kodeksu handlowego, wzorowany na francuskim Code de commerce z 1807 roku i na niemieckim kodeksie handlowym z 1861 roku.

Projekt Munzingera wywołał falę krytyki. Sprzeciw płynął głównie ze strony konserwatywnych kantonów romańskich, które w próbach narzucenia ustawodawstwa handlowego bez stosownego rozszerzenia drogą konstytucyjną kompetencji Związku widziały zamach na ich polityczną niezawisłość. Wyrażano także dezaprobatę wobec aktywizacji ustawodawczej kantonów niemieckich, co uznawano za przejaw „barbaryzacji”, tj. germanizacji rodzimej kultury prawnej $^{21}$. Ale głos sprzeciwu płynął również ze strony jednego z największych germanistów XIX stulecia, konserwatysty, profesora z Bazylei Andreasa Heuslera (1834-1921), według którego idea kodyfikacji stanowiła zagrożenie dla rozwoju rodzimej nauki prawa ${ }^{22}$. Były też wypowiedzi zwracające uwage na niedemokratyczny charakter projektu, przez nadawanie - abstrahując od przyjętego kryterium - uprzywilejowanej pozycji niektórym podmiotom obrotu handlowego.

Projektowi Munzingera po długich debatach parlamentarnych nie nadano dalszego biegu. Gdy w 1866 roku Rada Związku wezwała wszystkie kantony do zajęcia stanowiska w sprawie przyjęcia projektu w trybie konkordatowym, spory rozgorzały na nowo.

W latach 1867-69 forum dyskusyjnym były konferencje ogranizowane przez Juristenverein oraz stowarzyszenia przemysłowo-handlowe Berna, a głównym punktem debat stała się w ogóle celowość istnienia odrębnego kodeksu handlowego. Sprzeciw płynął głównie ze strony kantonów konserwatywnych, które, poza stałym punktem oporu, jakim była obawa przed utratą suwerenności politycznej, występowały teraz za pozostawieniem w nienaruszalnej postaci kantonalnych kodeksów cywilnych, jako zbiorów prawa najściślej związanych z miejscowymi obyczajami i kulturą prawną. Odżywały też hasła obrony porządku demokratycznego przeciw tworzeniu ius speciale

${ }^{21}$ Caroni, Rechtseinheit, s. 38.

${ }^{22}$ P. Liver, Das schweizerische Gesetzbuch. Kodifikation und Gesetzbuch, w: Privatrechtliche Abhandlungen, Berlin 1972, s. 103 n. Heusler wystąił też z krytyką projektu Munzingera pod hasłami utrzymania odrębności prawa handlowego, występującej w większości kodeksów kantonalnych. 
o znamionach przywileju stanowego. Natomiast ważnym argumentem zwolenników kodyfikacji był fakt, że sam Munzinger w motywach do projektu uznawał prawo handlowe za część ogólnego prawa zobowiązań, a czynności handlowe - za szczególny rodzaj czynności cywilnoprawnych ${ }^{23}$. Jako zwolennik ogólnoszwajcarskiej unifikacji prawa cywilnego uważał on kodeks handlowy za uzasadniony względami polityczno-gospodarczymi pierwszy etap prac kodyfikacyjnych. Dlatego też już w samym projekcie zawarł wiele przepisów z zakresu ogólnego prawa zobowiązań i rzeczowego (m.in. dotyczących nabywania ruchomości $)^{24}$.

W toku debat większość dyskutantów wypowiadała się przeciw wyodrębnianiu prawa handlowego. Zwyciężyła więc idea code unique, jednolitego kodeksu cywilnego, oczywiście rysująca się wówczas jeszcze jako wizja przyszłości. Natomiast ważnym realnym posunięciem w tym kierunku była inicjatywa konferencji kantonów z roku 1867/68 opracowania jednolitego międzykantonalnego prawa zobowiązań.

W roku 1869 Rada Związku powierzyła to zadanie komisji pod przewodnictwem W. Munzingera. Opracowany przezeń w 1871 roku projekt obejmujący część ogólną zobowiązań opierał się m.in. na prawie zobowiązań kodeksu cywilnego Zurychu oraz na projekcie drezdeńskim prawa zobowiązań z 1866 roku. Obrady nad projektem zostały przerwane, gdyż inicjatywie obywatelskiej rozszerzenia drogą rewizji konstytucji kompetencji Związku nie nadano dalszego biegu z powodu ustawicznych oporów niektórych kantonów przeciw ograniczaniu ich suwerenności w dziedzinie prawodawstwa.

V. Sytuacja polityczna Szwajcarii w początkach lat 70., której słabość militarna ujawniła się podczas wojny francusko-pruskiej, a także pojawienie się na mapie Europy dwóch potężnych sąsiadów, zjednoczonych Niemiec i Italii pod berłem dynastii sabaudzkiej, spowodowało aktywizację środowisk radykalnych zwolennikow centralizacji, domagających się zmian ustrojowych pod hasłem ein Recht und eine Armee.

W sferze gospodarczej czasy powszechnej industrializacji i zaostrzania sie fundamentalnego konfliktu między kapitałem a pracą spowodowały aktywizację nowych sił społecznych. W uprzemysłowionych regionach miejskich były to powstające $\mathrm{w}$ celach obrony interesów pracowników najemnych różnego typu ogranizacje branżowe, związki robotnicze, których wyrazicielem stanie się m.in. powstała w 1870 roku partia socjaldemokratyczna. Jej szeregi w późniejszych latach powiększać będą socjaldemokraci niemieccy, znajdujący

\footnotetext{
${ }^{23}$ Szerzej o stanowisku Munzingera i debatach nad jednolitym prawem zobowiązań P. Caroni, Der ,,demokratische” code unique von 1881, w: Das Obligationenrecht 1883-1983, Bern-Stuttgart 1984 s. 29 n.

${ }^{24}$ B. Dölemeyer, Das Schweizerische Obligationenrecht von 1881 (aOR) w: Handbuch III, 2 s. 1968 n.
} 
w Szwajcarii schronienie przed skutkami antysocjalistycznej polityki Bismarcka. Wszystkie te ugrupowania zasilały szeregi zwolenników centralizmu politycznego.

Pod naciskiem radykałów w 1872 roku podjęto prace nad rewizją konstytucji związkowej. Wyrazem radykalizacji nastrojów był postulat, by do kompetencji Związku zaliczyć m.in. całe ustawodawstwo w zakresie prawa cywilnego i procedury. Wprawdzie tak daleko idący wniosek przepadł (niewielką większością) w referendum ludowym, ale świadczył on o sile tendencji centralistycznych.

Kolejnym krokiem na drodze ku ogólnoszwajcarskiej unifikacji prawa cywilnego była dopiero przeprowadzona w 1874 roku nowelizacja konstytucji federalnej, polegająca na zmianie art. 64, który do kompetencji Związku zaliczył obecnie ,wszelkie materie prawne związane z handlem i obrotem towarowym”, tj. prawo zobowiązań (łącznie z prawem handlowym i wekslowym) ${ }^{25}$.

Punktem wyjścia prac kodyfikacyjnych był istniejący już projekt prawa zobowiązań z 1871 roku autorstwa W. Munzingera. Po jego śmierci w 1873 roku przewodnictwo komisji redakcyjnej obją Heinrich Fick. Prace komisji przeciagały się m.in. z powodu wymogu opracowania równoległego tekstu projektu w języku francuskim, z czym wiązały się trudności terminologiczne i konieczność dostosowania pojęć niemieckich do instytucji prawa francuskiego. Jednym z najważniejszych wątków przewijających się już od zarania prac unifikacyjnych były - jak pamiętamy - opory kantonów romańskich przeciw barbaryzacji ich dziedzictwa prawnego. W literaturze podnosi się, że, niezależnie od aspektów politycznych, nie chodziło tu o jakieś teoretyczne przeciwstawienie francuskiej i niemieckiej kultury prawnej, ale o rzeczywiste zróżnicowanie materii ustawowej, wynikające z faktu, że prawo niemieckie było $\mathrm{w}$ istocie znacznie bardziej zromanizowane niż system prawa francuskiego ${ }^{26}$. W dalszych etapach prac unifikacyjnych kwestia zharmonizowania stanowisk kantonów romańskich i niemieckich będzie miała znaczenie fundamentalne.

Punktem oparcia dla redaktorów projektu prawa zobowiązań był kodeks cywilny Zurychu, Code civil, ABGB, niemiecki kodeks handlowy z 1861 roku i projekt drezdeński prawa zobowiązań z 1866 roku. Wstępny projekt prawa zobowiązań został w 1877 roku przesłany do oceny przez zainteresowane gremia, m.in. sądy, uniwersytety, stowarzyszenia gospodarcze i korporacje praw-

${ }^{25}$ Art. 64 do kompetencji Związku zaliczał także prawo autorskie (własność literacką i artystyczną), prawo wynalazcze i upadłościowe oraz prawo o zdolności do działań prawnych, uregulowane ustawą związkową z 1888 roku.

${ }^{26}$ P. Caroni, Rechtseinheit, s. 40. Szersze uzasadnienie krytyki przyjmowanego w dawniejszej komparatystyce prawniczej zaliczania prawa francuskiego do romańskiej, a niemieckiego - do germańskiej rodziny prawnej vide K. Sójka-Zielińska, O stosowaniu metody porównawczej w historii prawa. P i P, 1963, z. 12, s. 837 n. 
nicze. Najwięcej uwag wniósł szwajcarski Juristenverein ${ }^{27}$. Zostały one dołączone do końcowej wersji projektu.

Ukończony projekt został w 1879 roku przedłożony Radzie Związku, która przesyłając tekst pod obrady obu izb Zgromadzenia Związkowego, dołączyła od siebie następujące dezyderaty:

1) projekt prawa zobowiązań ma odnosić się jednakowo do wszystkich uczestników obrotu, bez szczególnych regulacji dotyczących kupców,

2) w projekcie muszą być zharmonizowane i zunifikowane stanowiska kantonów romańskich i niemieckich,

3) ustawa ma obejmować przepisy prawa rzeczowego o przenoszeniu własności rzeczy ruchomych.

Prawo zobowiązań zostało uchwalone przez obie izby 14 czerwca 1881 roku z mocą obowiązującą od 1883 roku, pn. Bundesgesetz über das Obligationenrecht (OR). Regulowało ono, obok przepisów części ogólnej i szczególnej prawa zobowiązań, prawa rzeczowe odnoszące się do obrotu ruchomościami, prawo handlowe i wekslowe. Tym samym została zrealizowana - wbrew zwolennikom odrębności prawa handlowego - idea code unique, jednolitego prawa prywatnego. Konstrukcja przyjęta przez ustawodawcę szwajcarskiego miała na celu m.in. uproszczenie systemu źródeł prawa przez uniknięcie występującego w systemie francuskim i niemieckim dublowania niektórych regulacji prawnych ${ }^{28}$. Wprawdzie kodyfikacja pod względem techniki ustawodawczej wykazywała pewne niedostatki, ale stanowiła duży krok w kierunku przyszłej ogólnozwiązkowej unifikacji prawa prywatnego.

Uchwalenie kodeksu zobowiązań otwierało niezwykle ważny i trudny etap przewidzianej $\mathrm{w}$ przepisach przejściowych konieczności dostosowania praw miejscowych do jego unormowań, a więc i przeredagowania wszystkich kantonalnych kodeksów cywilnych. Proces dostosowawczy, podejmowany w atmosferze niechęci ze strony sporej części kantonów, wywoływał też liczne komplikacje w praktyce sądowej, stawiając przed sędziami niemal na każdym kroku konieczność rozstrzygania przypadków kolizji norm, co w społeczeństwie pogłębiało poczucie braku pewności prawnej. Okazało się, że w praktyce koegzystencja kantonalnych systemów prawa prywatnego z ustawodawstwem ogólnozwiązkowym jest na przyszłość nie do utrzymania, gdyż godzi w interesy ekonomiczne kraju. Jako jedyne rozwiązanie rysowało się więc ujednolicenie prawa cywilnego w skali całego Związku ${ }^{29}$.

\footnotetext{
${ }^{27}$ Krytykowano m.in. przepisy ograniczające swobodę umów towarzystw akcyjnych i ubezpieczeniowych oraz zaczerpnięty z prawa francuskiego sposób przenoszenia własności ruchomości. B. Dölemeyer, w: Handbuch, 1. c., s. 1972.

${ }^{28}$ W końcowej wersji OR z 1911 r. poszczególne rozwiązania zbliżały się bardziej do niemieckiego modelu prawa handlowego. A. Klimaszewska, Code de commerce. Francuski kodeks handlowy z 1807 r. Gdańsk 2011, s. 173.

${ }^{29}$ P. Caroni, Rechtseinheit, s. 23.
} 
VI. Nowy etap dążeń do jedności prawnej Związku otworzyła inicjatywa szwajcarskiego Juristenverein, który w roku 1884 wystąpił z wnioskiem podjęcia badań porównawczych wszystkich kantonalnych systemów prawa prywatnego z myślą o przyszłej ogólnonarodowej unifikacji. Zadanie to powierzono ówczesnemu prezesowi Stowarzyszenia, germaniście, Eugenowi Huberowi, który zasłużyć miał na miano „ojca kodeksu cywilnego”.

Eugen Huber (1849-1923) po ukończeniu studiów prawniczych w Zurychu i Berlinie oraz uzyskaniu habilitacji w 1873 roku przez kilka lat pracował m.in. jako sprawozdawca parlamentarny, publicysta i redaktor naczelny „Neue Zürcher Zeitung". W 1882 roku został docentem prywatnym szwajcarskiego prawa cywilnego, prawa państwowego i historii prawa w Bazylei, a także (w latach 1882-1892) był profesorem niemieckiego prawa handlowego i prawa państwowego na uniwersytecie w Halle-Wittemberdze.

Od 1884 roku Huber zgodnie z wnioskiem Juristenverein przystapił do zebrania i porównawczego opracowania wszystkich kantonalnych zbiorów prawa prywatnego i lokalnych praw zwyczajowych. Wynikiem prac było opublikowanie w latach 1886-1893 fundamentalnego 4-tomowego dzieła System und Geschichte des Schweizerischen Privatrechts.

W roku 1892/93 Huber objął katedrę w Bernie, co było związane z powołaniem go przez dyrektora Związkowego Departamentu Sprawiedliwości i Policji do opracowania projektów pozostałych części kodeksu cywilnego.

Rozpoczął działalność od przedstawienia planu prac. W memoriale z 1893 roku szeroko uzasadniał konieczność unifikacji prawa cywilnego. Na pierwszy plan wysuwał interesy ekonomiczne kraju, potrzeby bezpieczeństwa obrotu, szczególnie pilne wobec wzrostu procesów migracji ludności. Za ważne uznał też zapewnienie obywatelom należytej opieki prawnej przez usuwanie nieprawidłowości w praktyce orzecznictwa, jak spory dotyczące właściwości sądów, kolizje między prawami lokalnymi a ustawodawstwem związkowym itp. Chodziło też o moderowanie różnic między systemami prawnymi kantonów niemieckich, francuskich i włoskich, wynikających z ich przywiązania do tradycji prawnej obcych ustawodawstw, co w dużej mierze utrudniało rozwój narodowej nauki prawa ${ }^{30}$. Przed Huberem stanęło zadanie przełamywania sprzeciwu środowisk konserwatywnych wobec wkraczania $\mathrm{w}$ miejscowe urządzenia prawne i tradycje kulturowe droga poszukiwania porozumienia między będącymi w mniejszości kantonami romańskimi i kantonami niemieckimi, stanowiącymi siłę napędową procesu ogólnozwiązkowej kodyfikacji. Najsilniejsze opory występowały ze strony francuskojęzycznych kantonów zachodnioszwajcarskich należących do kręgu kulturowego Code civil oraz kilku kanto-

${ }^{30}$ B. Dolemeyer, Handbuch III, 2, s. 1989. W wydanym w związku z memoriałem Hubera okólnikiem rządowym z 1896 roku zwracano szczególną uwagę na zbyt duży wpływ na cywilistykę szwajcarską nauki niemieckiej. 
nów Szwajcarii środkowej (m.in. Uri, Schwyz, Oberwalden), w których nie doszło do skodyfikowania prawa i nadal posługiwano się prawami lokalnymi, w większości zwyczajowymi.

Huber stanął wobec konieczności znalezienia kompromisu między wymogami budowy nowoczesnego systemu prawnego a - stanowiącym dlań godną pełnego respektu wartość - przywiązaniem kantonów konserwatywnych do lokalnych tradycji prawa. Drogą do tego celu miało być wydobywanie i stosowne przekształcanie tych dawnych instytucji prawnych, które - jak pisał „mogłyby sprostać wymogom teraźniejszości i przyszłości”31.

Eugen Huber przystępował do pracy w czasach końcowej fazy dyskusji nad projektem BGB i jego krytyki. Płynęła ona wprawdzie z dwóch różnych stron (z jednej strony germanistów z Ottonem v. Gierke na czele, a z drugiej - socjaldemokratów pod przewodem Antona Mengera), ale kierowana była podobnymi pobudkami. Były nimi hasła solidaryzmu społecznego; ochrony przez państwo ekonomicznie słabszych jednostek przed egoizmem bogatych.

Otto v. Gierke (1841-1821), profesor uniwersytetu w Berlinie, czołowy uczony z kręgu ówczesnej germanistyki, podjął generalną krytykę indywidualistycznego charakteru projektu BGB, jako tworu nauki pandektów obcego „duchowi” prawa niemieckiego, jego tradycjom i zwyczajom prawnym. W swym słynnym wystapieniu przed gremium Wiedeńskiego Towarzystwa Prawniczego „o społecznym zadaniu prawa prywatnego” (Die soziale Aufgabe des Privatrechts, Berlin 1889) postulował powrócenie ustawodawcy do tradycji germańskich wspólnot społecznych, w których uprawnienia jednostki były ograniczane obowiązkami wobec zbiorowości ${ }^{32}$.

Wśród socjaldemokratów niemieckich największy rozgłos zyskały wystąpienia wiedeńskiego profesora procesu cywilnego, socjalisty ex cathedra Antona Mengera, który w pracy Das bürgerliche Recht und die besitzlosen Volksklassen (Tübingen 1890) dowodził, że ustawodawstwo, które w sposób formalistyczny ustanawia jednakowe reguły prawne dla bogatych i biednych, a więc także sankcjonowana przez projekt abstrakcyjna zasada autonomii woli, czy też formalnej równości podmiotów wobec prawa, prowadzi w istniejącej sytuacji społeczno-gospodarczej do skrajnej nierówności, będącej niewolą dla ekonomicznie słabszych. W obliczu kryzysu liberalizmu ekonomicznego i zaostrzających się przeciwieństw między kapitałem a pracą, jego program rozwiązywania konfliktów społecznych drogą interwencjonizmu państwowego zyskał też popularność w kantonach niemieckich konfederacji nie tylko w środowiskach szwajcarskich socjaldemokratów, ale i w uniwersyteckich kręgach naukowych.

${ }^{31}$ B. Dölemeyer, Handbuch, 1. c., s. 1990.

${ }^{32}$ A. Laufs, Rechtsentwicklungen in Deutschland, wyd. IV, Berlin-New York 1991, s. 269 n. 
VII. W ułożonym przez siebie wstępnym planie prac Huber wymieniał kilka kluczowych problemów do rozwiązania, wyraźnie inspirowanych doświadczeniami prac nad projektami BGB i jego krytyką od strony skutków społecznych.

1. W prawie osobowym małżeńskim wprawdzie kwestia zasadnicza, jaką było uznanie obligatoryjnego charakteru małżeństwa cywilnego, została już uregulowana na mocy ogólnozwiązkowej ustawy z 1874 roku $^{33}$, jednak zdaniem Hubera w przyszłym kodeksie należało z jednej strony bardziej wyeksponować pozycję męża, jako głowy rodziny, ale z drugiej - uwzględniać w pewnej mierze postulaty rodzącego się wówczas ruchu emancypacyjnego kobiet, m.in. przez zniesienie istniejącej jeszcze gdzieniegdzie instytucji opieki mężowskiej, czy przez zapewnienie kobietom swobody podejmowania pracy zawodowej.

2. W dziedzinie prawa spadkowego plan Hubera polegał na utrzymaniu, zgodnie z ideologią liberalizmu, swobody jednostki dysponowania majątkiem na wypadek śmierci, ale jednocześnie na uwzględnianiu aspektów społecznych spadkobrania, m.in. przez ograniczanie kręgu spadkobierców ustawowych i rozszerzeniu praw państwa do spadku bezdziedzicznego. Przykład ten dowodził, że twórcy ZGB, w przeciwieństwie do redaktorów BGB stojących w tej materii na pozycjach skrajnego liberalizmu, kładli silniejszy nacisk na społeczne potrzeby ochrony ekonomicznie słabszych, co zresztą leżało w zakorzenionych tu od wieków tradycjach wspólnotowych szwajcarskich praw kantonalnych.

3. Idee ochrony interesu społecznego znalazły też wyraz w planach Hubera reformy prawa rzeczowego, m.in. w kierunku racjonalizacji gospodarki rolnej, co wiązało się ze sprawą rozszerzania możliwości udzielania kredytu pod zastaw nieruchomości, a uregulowanie prawa hipotecznego należało wówczas do najpilniejszych zadań ustawodawczych. W programie Hubera znalazł się też postulat zmian dostosowawczych w prawie zobowiązań z 1881 roku.

Huber zapraszał do współpracy przedstawicieli wszystkich kantonów, grup językowych, obszarów prawnych i partii politycznych, mając na uwadze nie tylko ich naukowe czy praktyczne przygotowanie, ale głównie zjednanie konserwatystów, obrońców partykularyzmu prawnego i politycznych adwersarzy, a zwłaszcza załagodzenie konfliktu między będącymi w mniejszości kantonami romańskimi i kantonami niemieckimi. Konflikt ten nabrał również zabarwienia ideologicznego, który był przedstawiany w ówczesnej literaturze francuskiej, jako starcie entre la majorité suisse allemande étatiste et la minorité Suisse romande individualiste ${ }^{34}$.

${ }^{33}$ Bundesgesetz betr. Feststellung und Beurkundung des Zivilstandes und der Ehe. vide Herbert. Kundert w: Handbuch der Quellen, III, 2 s. 2035.

${ }^{34}$ P. Caroni, Rechtseinheit, s. 43 przyp. 124. Opory kantonów romańskich osłabły, gdy związkowe prawo zobowiązań oraz uregulowane w ustawach szczególnych prawo egzekucyjne i upadłościo- 
W latach 1893-1898 Eugen Huber opracował trzy częściowe projekty wstępne $\mathrm{z}$ dziedziny prawa rodzinnego, spadkowego i rzeczowego, które przedstawił Radzie Związku wraz z memoriałem, zawierającym plan i zakres przyszłej jednolitej kodyfikacji prawa prywatnego oraz postulat stosownej zmiany art. 64 konstytucji. W 1898 roku obie izby Zgromadzenia Związkowego uchwaliły uzupełnienie art. 64 o zdanie rozszerzające kompetencję Związku na wszystkie dziedziny prawa cywilnego.

Opracowane przez Hubera projekty częściowe po naradach w wąskim gronie ekspertów i nowym zredagowaniu tekstów w języku niemieckim i francuskim zostały w 1900 roku opublikowane, jako oficjalny rządowy projekt wstępny do dalszych dyskusji. Do projeku rządowego dołączony został opracowany przez Hubera w latach 1900-1902 komentarz (Erläuterungen) zawierający założenia ogólne kodyfikacji ${ }^{35}$. Do kierowania pracami powołano 31-osobową komisję ekspertów, której część stanowili członkowie parlamentu, a pozostali reprezentowali różne kręgi praktyków i teoretyków prawa. Wezwano też - zgodnie z planem Hubera z 1893 roku - wszystkie zainteresowane krajowe instytucje, partie polityczne i kręgi zawodowe do przesyłania uwag.

Merytoryczna dyskusja nad projektem miała w każdym stadium charakter publiczny, w szerokim zakresie dopuszczono udział obywateli i grup interesów. Redaktorom chodziło tu o uniknięcie sytuacji, jaka miała miejsce w czasie debat nad II projektem BGB i zaciążyła na ich przebiegu.

W latach 1904-1906 toczyły się obrady w specjalnych komisjach obu izb parlamentu, w których - obok członków komisji ekspertów - reprezentowane były ugrupowania partyjne, wszystkie kantony i obszary językowe. Końcowy projekt po obróbce tekstu od strony technicznej przez komisję redakcyjną wraz z przekładem tekstu na język włoski, przesłano na forum Zgromadzenia Związkowego, gdzie 10 grudnia 1907 roku został przez obie izby parlamentu jednogłośnie przyjęty pn. Schweizerisches Zivilgesetzbuch, Code civil suisse, Codice civile svizzero (ZGB), z mocą obowiązującą od 1 stycznia 1912 roku.

Jeszcze w roku 1901 komisja Departamentu Sprawiedliwości i Policji w nawiązaniu do występującego w memoriale Hubera z 1893 roku postulatu rewizji prawa zobowiązań (OR) powołała do życia specjalną komisję pod jego kierownictwem w celu dostosowania przepisów do projektów pozostałych części kodeksu i ich koniecznej modernizacji.

we okazało się lepiej dostosowane do ówczesnych realiów życia społeczno-gospodarczego niż rozwiązania Code civil z anachronicznym modelem kredytu hipotecznego. Nieustępliwe pozostały jedynie dwa katolicko-konserwatywne kantony, Wallis i Fryburga (tamże, s. 44 n.).

${ }^{35}$ E. Huber, Erläuterungen zum Vorentwurf des Eidgenossischen Justiz und Polizeidepartamentes. 1902. II wydanie Motywów ukazało się drukiem w 1914 r. w Bernie. Ich fragmenty zamieszcza P. Caroni w: Gesetz und Gesetzbuch. Beiträge zu einer Kodifikationsgeschichte, Basel-Genf-München 2003 (w aneksie). 
Warto w tym miejscu wspomnieć, że w aktywności naukowej, publicystycznej i legislacyjnej Hubera prawo zobowiązań zajmowało poczesne miejsce. Już od 1883 roku, tj. od wejścia w życie OR, wykładał on część ogólną szwajcarskiego prawa zobowiązań, a odnalezione w latach 50 . XX wieku w archiwaliach berneńskich manuskrypty wykładów były pierwszym tak gruntownym naukowym opracowaniem kodeksu i to przy zastosowaniu siatki pojęciowej zaczerpniętej z instrumentarium ówczesnej pandektystyki. Pozwalało to dzisiejszym badaczom widzieć w Huberze również wytrawnego znawcę prawa rzymskiego ${ }^{36}$.

Plan prac komisji przewidywał ograniczenie ram procesu dostosowawczego przez wyłącznie zeń przepisów prawa wekslowego, akcyjnego oraz prawa o stowarzyszeniach, które ze względu na konieczność częstych nowelizacji i na powiązania $\mathrm{z}$ obrotem międzynarodowym miały być wydane $\mathrm{w}$ formie ustaw szczególnych.

Prace dostosowawcze polegały, poza ujednoliceniem słownictwa, na przeniesieniu do kodeksu cywilnego materii nienależących do prawa zobowiązań, jak np. przepisów z zakresu prawa o ruchomościach, ogólnej zdolności do działań prawnych, odpowiedzialności z tytułu zobowiązań małoletnich i kobiet zamężnych itp. Jednocześnie postulowano uzupełnienie prawa zobowiązań o przepisy o nabywaniu gruntów, darowiznach itp., które dawniej były regulowane w prawach kantonalnych.

W pracach nad rewizją prawa zobowiązań głównym punktem sporów między różnymi grupami interesów było uregulowanie umowy o pracę (Lohnvertrag), a obrady komisji zdominowały starcia między przedstawicielami organizacji pracodawców i reprezentującej stronę pracowniczą partii socjaldemokratycznej. Komisja, wykorzystując doświadczenia przeszło 20 lat funkcjonowania prawa zobowiązań, wprowadziła szereg nowych rozwiązań oraz radykalnie rozszerzyła przepisy dotyczące umów o pracę.

Projekt ustawy dostosowawczej w postaci V części kodeksu cywilnego został w 1905 roku przedstawiony obu izbom Zgromadzenia Związkowego, jednak nie uzyskał akceptacji. Parlament zdecydował, by prace nad ustawą wstrzymać aż do czasu uchwalenia pozostałych części kodeksu.

Powołana w 1908 roku wielka komisja ekspertów do rewizji prawa zobowiązań, której głównym referentem był znów Eugen Huber, przedstawiła w roku następnym wyniki prac. Nowa ustawa ograniczała się, z powodu krótkich terminów przewidzianych do rewizji i ujednolicenia tekstu z kodeksem cywilnym tylko do pierwszych 23 tytułów prawa zobowiązań ${ }^{37}$. Uchwalona

${ }^{36}$ K.H. Kaufmann, Das Schweizerische Obligationenrecht, w: Das Obligationenrecht 1883-1983 , Bern u. Stuttgart 1984, s. 82.

${ }^{37}$ Tytuły te obejmowały ogólne prawo umów, odpowiedzialność z tytułu czynów niedozwolonych, niesłusznego wzbogacenia oraz poszczególne typy umów. Rewizja tytułów 24-33, obejmujących normy prawa handlowego, jak również osobno opracowane prawo wekslowe, akcyjne i stowarzyszeniowe, miały nastąpić w terminach późniejszych. H. Schlosser, Grundzüge, s. 171. 
30 marca 1911 roku ustawa związkowa (Bundesgesetz betreffend die revidierten Titel 1-23 des Obligationenrechts) weszła w życie 1 stycznia 1912 roku jednocześnie z kodeksem cywilnym jako jego V część, Obligationenrecht, ale opublikowana została odrębnie z zachowaniem własnej numeracji przepisów ${ }^{38}$.

Wraz z wejściem w życie ZGB na podstawie art. 51 tytułu końcowego została uchylona moc obowiązująca praw kantonalnych, ale przewidziano tu szereg wyjątków: np. kantonom pozostawiono uchwalanie przepisów wprowadzających, utrzymano w mocy prawo kantonalne wszędzie tam, gdzie odwoływano się do zwyczajów miejscowych (art. 5 tytułu wstępnego). Utrzymano także kompetencje ustawodawcze kantonów w materiach, które przysługiwały im na mocy konstytucji (m.in. organizacja sądownictwa i procedury cywilnej).

VIII. Ogólne założenia kodeksu cywilnego (ZGB) Eugen Huber wyłożył we wspomnianym już komentarzu (Erläuterungen) dołączonym do oficjalnego projektu rządowego z 1900 roku. Przystępując do prac redakcyjnych, Huber dysponował ogromnym materiałem normatywnym. Składały się nań nie tylko wszystkie opracowane przezeń porównawczo kodeksy kantonalne oraz inne lokalne źródła prawa, ale też ustawodawstwo cywilne i handlowe całej niemal kontynentalnej Europy z tzw. „wielkimi kodyfikacjami” na czele. Cenił sobie płynące stąd doświadczenia, ale czerpał z nich tylko te elementy, które były przydatne do realizowania własnej nowatorskiej koncepcji kodeksu. Jego ambicją było samodzielne zbudowanie dzieła oryginalnego zarówno pod względem formy, jak i treści. Jak pisał w swym komentarzu,

nie można zapominać, że każda instytucja prawna powstawała w pewnym jej tylko właściwym kształcie i wyrastała $\mathrm{z}$ własnych korzeni [...]. Tylko w ścisłym powiązaniu z określonymi warunkami życiowymi można zdecydować, czy jej przesadzenie na obcy grunt byłoby celowe, a nawet w ogóle możliwe [...]. Należy poszukiwać właściwych rozwiązań na naszym własnym gruncie i zgodnych z naszymi warunkami życiowymi, tak, jak czyniły to u siebie inne kraje ${ }^{39}$.

Kodeks powstawał już po wejściu w życie BGB i ujawnieniu się wad formalnych tej wielkiej kodyfikacji, będącej szczytowym osiagnięciem ,jurysprudencji pojęciowej”. Krytykowano skomplikowaną strukturę dzieła, zwłaszcza niezmiernie rozbudowaną technikę odesłań z jednych paragrafów do innych, abstrakcyjny charakter unormowań, przeładowanie trudną, sztucznie

${ }^{38}$ Wkrótce po wejściu w życie prawa zobowiązań ujawniła się potrzeba dostosowania do nowych warunków prawa spółek handlowych, podstawowych instytucji prawa handlowego, oraz regulacji papierów wartościowych. Generalna reforma prawa zobowiązań nastapiła w 1936 r. A. Całus, Przewodnik po źródlach i podstawowych instytucjach prawa prywatnego (handlowego) w systemach prawnych Europy kontynentalnej, Wlk. Brytanii i USA, Warszawa 1992, s. 136 n.

${ }^{39}$ E. Huber, Erläuterungen, wyd. II Bern 1914, B I, s. 6-7, cyt. według tekstu zamieszczonego w aneksie przez P. Caroniego, Gesetz, s. 367. 
tworzoną terminologią, hermetyczny, daleki od rodzimej tradycji językowej, prawniczo-biurokratyczny Juristendeutsch niezrozumiały dla laika, drobiazgowość prowadzącą do rażącej w nowoczesnej technice legislacyjnej kazuistyki. Pozwoliło to Huberowi na uniknięcie wszystkich tych powszechnie krytykowanych wadliwości formalnych kodeksu niemieckiego.

ZGB składa się z tytułu wstępnego (art. 1-10) oraz 4 części (Teile, livres): prawa osobowego (art. 11-89), familijnego (art. 90-456), spadkowego (art. 457-640) i rzeczowego (art. 641- 977), podzielonych na działy (Abteilung, partie), tytuły, rozdziały i artykuły. Wyodrębniona piąta część, opublikowana jako odrębna ustawa pt. Obligationenrecht, liczy 1186 artykułów, składając się obecnie z 5 części $^{40}$.

Przyjęta systematyka opiera się, z grubsza biorąc, na podziale materii kodeksowej na 5 części, opracowanym w nauce pandektów, ale zastosowano tu odmienną niż w BGB kolejność. To, że na końcu znalazło się prawo zobowiązań, wynikało nie tylko z kolejności prac nad redagowaniem kodeksu, ale i z przekonania natury etycznej, że prawo osobowe i familijne powinno mieć pierwszeństwo przed prawem obrotu majątkowego ${ }^{41}$.

Podczas prac nad BGB wielce dyskusyjna była kwestia celowości wyjęcia „przed nawias” norm o charakterze ogólnym, dotyczących całej materii kodeksu, w postaci „,części ogólnej” ${ }^{2}$. Koncepcja ta wynika z typowej dla nauki pandektów tendencji do tworzenia abstrakcyjnych schematów pojęciowych. Krytycy dowodzili, że przepisy części ogólnej nie są wcale „ogólnymi” dla całego prawa cywilnego; że takie pojęcia, jak „osoby fizyczne”, „osoby prawne”, „rzeczy”, są po prostu częściami prawa osobowego czy rzeczowego i nie ma żadnej potrzeby ich wyodrębniania, tym bardziej że w części szczegółowej wprowadzono szereg wyjątków od jej reguł. Wskazywano ponadto, że formułowanie ,pojęć ogólnych” należy do zadań doktryny, a nie prawodawcy.

Struktura kodeksu szwajcarskiego została pod tym względem znacznie uproszczona, m.in. przez zastąpienie „części ogólnej” złożonym z 10 artykułów tytułem wstępnym (Einleitung, Titre préliminaire).

Najważniejszym zadaniem, jakie stawiał sobie Huber pod względem formy kodeksu, była prostota stylu, osiagnięcie jego powszechnej zrozumiałości, przez operowanie językiem jasnym, czytelnym, przystępnym dla każdego. Poszczególne artykuły miały być zwięzłe. Każdy z nich musiał być zrozumiały

${ }^{40}$ Prawo zobowiązań dzieli się na: I. postanowienia ogólne, II. poszczególne stosunki umowne, III. spółki handlowe i spółdzielnie, IV. rejestry handlowe, V. papiery wartościowe. Specyfiką kodyfikacji szwajcarskiej jest to, że nowelizacje nie ukazują się w postaci odrębnych ustaw, ale są włączane do pierwotnego tekstu. Stąd nie zmienia się numeracja przypisów, ale powiększa się nieraz kilkakrotnie ich objętość. A. Całus, Prawo cywilne i handlowe państw obcych. Warszawa 1985, s. 35 n.

${ }^{41}$ K. Zweigert - H. Kötz, Einführung in die Rechtsvergleichung, I, Tübingen 1984, s. 197.

${ }^{42}$ O sporach wokół tzw. ,części ogólnej” F. Wieacker, Privatrechtsgeschichte der Neuzeit, Göttingen 1967, s. 486. 
sam z siebie, tak by unikać odesłań, a ponadto zaopatrzony w streszczenie jego zawartości na marginesie. Również kolejność artykułów miała być ułożona według logicznego porządku. Sprawa jasności i czytelności tekstu miała w realiach ustroju politycznego Szwajcarii wymiar wagi konstytucyjnej. W systemie demokracji bezpośredniej, gdzie udział w stanowieniu ustaw mieli sami obywatele i uchwalali je dla siebie, musiały być one dostosowane stylem do mentalności i odczuć tzw. „prostego człowieka”43.

Prostota stylu kodeksu wiązała się także ze specyfiką szwajcarskiego ustroju sądownictwa, wynikającą z braku wykwalifikowanych kadr prawniczych. W ówczesnym systemie wymiaru sprawiedliwości osoby powoływane w drodze wyborów do sądzenia spraw cywilnych miały na ogół słabe przygotowanie merytoryczne do tych funkcji. Dotyczyło to zwłaszcza sędziów orzekających w I instancji. Ponieważ w systemie demokracji bezpośredniej obywatele brali udział zarówno w stanowieniu, jak i w wykonywania prawa, problem relacji: ustawodawca-sędzia nabierał tu szczególnego wymiaru.

Kodeks szwajcarski powstawał w czasach załamywania się podstaw doktrynalnych pozytywizmu ustawowego. Wejście w życie BGB stawiało przed doktryną konieczność dostosowania teorii wykładni naukowej do potrzeb praktyki sądowej. W czasach burzliwych przemian gospodarczych i konfliktów społecznych odeszła w zapomnienie, utrzymywana przez ,jurysprudencję pojęciową", fikcja braku luk w kodeksie. Istotnym problemem stał się więc sposób procedowania sędziego $\mathrm{w}$ razie milczenia ustawy.

Powstały nowe nurty doktrynalne mające na celu opracowanie dla potrzeb judykatury nowych metod wykładni prawa, a nawet dążenia do „uwolnienia" sędziów od wszelkich rygorów interpretacyjnych ${ }^{44}$. Eugen Huber, który utrzymywał ścisłe kontakty z czołowymi przedstawicielami nowych kierunków niemieckiego prawoznawstwa, zapewne czerpał stamtąd pewne inspiracje, ale przyjęte $\mathrm{w}$ art. 1 ZGB zasady orzekania w razie milczenia ustawy były ściśle związane ze specyfiką szwajcarskiego wymiaru sprawiedliwości. Staną się one

${ }^{43}$ Kodyfikację szwajcarską cechował świadomy brak precyzji sformułowań, niedokładność, niezupełność regulacji kodeksowych. Jednak te celowe zabiegi formalne miały również ujemne strony. P. Caroni, Gesetz, s. 82 n. Jednym z głośnych krytyków języka ZGB był Ernst Rabel (1874-1955), międzynarodowej sławy znawca prawoznawstwa porównawczego. P. Liver, Das Schweizerische Gesetzbuch. Kodifikation und Rechtswissenschaft, w: Privatrechtliche Abhandlungen, Bern 1972, s. 112 n.

${ }^{44}$ Pierwszym wyłomem w gmachu ,jurysprudencji pojęć” była ,jurysprudencja celowościowa (Zweckjurisprudenz), której założenia sformułował w latach 80. Rudolf Ihering. Do niej nawiązywał nowy kierunek doktrynalny powstały wśród uczonych z Tybingi (m.in. Philippa Hecka i Maxa Rümelina), zwany jurysprudencją interesów (Interessenjurisprudenz), mający na celu opracowanie dla potrzeb judykatury nowych reguł interpretacji prawa, który nie wykraczał początkowo poza ramy wykładni tradycyjnej. Ale pod naporem kierunków modernistycznych, szczególnie „szkoły wolnego prawa" (Freirechtsschule) z Eugenem Ehrlichem i Hermanem Kantorowiczem na czele, występujących pod hasłami „uwolnienia” sędziów od więzów dotychczasowych metod wykładni, dopuszczono swobodę wypełniania luk w ustawie przez sędziego, tak jakby sam był ustawodawcą. 
z kolei punktem odniesienia, a zarazem jednym z najżywiej dyskutowanych problemów cywilistyki europejskiej.

Uznawany za najbardziej znany w cywilistyce światowej przepis kodeksu szwajcarskiego art. 1 ZGB regulował zasady wykładni. W ustępie 1 głosił on, że ustawa reguluje wszystkie materie, do których odnosi się litera lub duch danej dyspozycji kodeksowej. Ustęp 2 tego artykułu przewidywał, że w razie braku stosownej normy ustawowej sędzia powinien wyrokować na podstawie prawa zwyczajowego, a w razie jego milczenia - według prawidła, które by sam ustanowił, gdyby był prawodawcą.

Przepis art. 1, który na pozór zrównywał pozycję sędziego i ustawodawcy, witany był przez modernistów jako wyraz ustawowego usankcjonowania haseł niemieckiego ruchu wolnego prawa, czy też jego francuskiej odmiany szkoły wolnych poszukiwań naukowych (Libres recherches scientifiques) François Gény'ego ${ }^{45}$. W rzeczywistości jednak przepis ten nie dopuszczał samowoli w wyrokowaniu. Przede wszystkim już sam art. 1 w ust. 3 wprowadzał - co w naukowych dysputach nie zawsze bywa uwzględniane - wyraźne ograniczenia swobody sędziego, stanowiąc, że kieruje się on przy rozstrzyganiu sprawy rozwiązaniami utrwalonymi w nauce i orzecznictwie (folgt dabei bewährter Lehre und Überlieferung; il s'inspire des solutions consacrées par la doctrine et jurisprudence). Przepis ten otwierał tym samym przed prawoznawstwem i orzecznictwem sądowym nowe zadania na przyszłośćc ${ }^{46}$.

Specyfiką szwajcarskiego systemu wymiaru sprawiedliwości od czasu zerwania związków z uniwersytetami niemieckimi u schyłku XV wieku był brak wykształconych kadr prawniczych i administracyjnych. Funkcję sądzenia powierzano obywatelom najbardziej godnym zaufania, a za kryterium wyboru sędziów uznawano nie tyle znajomość prawa, ile przymioty osobiste i doświadczenie życiowe. Poza tym sędziowie, jako funkcjonariusze publiczni obdarzeni zaufaniem wyborców, czuli się zobowiązani do przestrzegania reguł obiektywizmu. Mówi się nawet, że sędziowie szwajcarscy w pewnym stopniu zawiedli oczekiwania ustawodawcy; gdyż w obawie przed skutkami nadużywania przyznanej im swobody interpretacyjnej, woleli nie wykraczać w praktyce poza tradycyjne metody wykładni ${ }^{47}$.

${ }^{45} \mathrm{~W}$ związku z art. 1 ZGB F. Gény pisał: ,po raz pierwszy, być może, widzi się nowoczesnego ustawodawcę, uznającego oficjalnie sędziego jako swą nieodzowną pomoc". Zweigert - Kötz, Einführung, s. 208. O programie szkoły tzw. wolnych poszukiwań naukowych, K. Sójka-Zielińska, Kodeks Napoleona. Historia i wspótczesność, Warszawa 2007, s. $171 \mathrm{n}$.

${ }^{46}$ Wśród zadań stojących przed szwajcarską nauką prawa wymieniano m.in. popularyzację wiedzy o kodeksie cywilnym w społeczeństwie, systematyzację naukową materii kodeksowej umożliwiającą formułowanie uogólnień, zacieśnianie współpracy z judykaturą, rozwój badań historycznoprawnych i prawnoporównawczych. A. Egger, Schweizerische Rechtssprechung und Rechtswissenschaft, Berlin 1913 s. 33 n. (Mowy rektorskie na uniwersytecie w Zurychu).

${ }^{47}$ P. Caroni, Gesetz, s. 80. Art. 1 ZGB budził też ówcześnie zainteresowanie cywilistów polskich w zaborze austriackim. Ernest Till, wielce krytyczny wobec „szkół wolnego prawa”, w wyda- 
IX. Kryzys pozytywizmu prawniczego spowodował pojawienie się na przełomie stuleci nowych kierunków doktryny cywilistycznej - teorii odrodzonego prawa natury, które podstaw prawoznawstwa szukały w sferze ponadustawowych wartości moralnych. Na gruncie niemieckiej filozofii prawa będą to różne nurty ideowe połączone wspólnym hasłem ,powrotu do Kanta”. Ich czołowym wyrazicielem stanie się Rudolf Stammler (1856-1938), twórca teorii prawa natury o zmiennej treści, którą wyłoży w wydanej w 1902 roku Nauce o shusznym prawie.

Neokantyzm nawiązywał tu do starożytnej filozofii prawa natury i konfliktu między prawem oficjalnym a normami moralnymi, owego sławnego dylematu, przed którym stanęła ongiś bohaterka tragedii Sofoklesa, Antygona.

U Arystotelesa wyraził się on wprowadzeniem pojęcia słuszności (epieikeia), służącej łagodzeniu w praktyce sądowej norm prawa pozytywnego tam, gdzie rozmijało się z poczuciem naturalnej sprawiedliwości. W Rzymie pod wpływem stoicyzmu jurysprudencja będzie szeroko podejmować problemy wartości etycznych prawa i szukania kompromisu między rygorystycznym jego przestrzeganiem (dura lex sed lex) a cycerońską maksymą summum ius summa iniuria. Wśród instrumentów stosowania prawa pretorskiego na pierwszym planie znajdzie się słuszność, aequitas, dla osiagnięcia ideału prawa, zawartego w fundamentalnej regule: ius est ars boni et aequi.

Wielkie kodyfikacje cywilne epoki Oświecenia, budowane na podstawach filozoficznych nowożytnego prawa natury, dopuszczały początkowo wśród metod wykładni sięganie do naturalnych zasad prawnych (ABGB), czy też do prawa natury, jako źródła wszelkich praw pozytywnych (projekt $\mathrm{KN}$ z roku VIII). Jednak te furtki interpretacyjne zamknęły się w czasach panowania szkoły egzegezy i pozytywizmu prawniczego $0^{48}$.

Filozofia odrodzonego prawa natury nie wywarła wpływu na ostateczny kształt kodyfikacji niemieckiej. Głośna dyskusja nad dwoma projektami BGB doprowadziła w ostatniej fazie prac do zamieszczenia nielicznych tylko i wąsko pojmowanych zasad etycznych (np. § 138 BGB przewidujący nieważność umów sprzeciwiających się dobrym obyczajom), a rozsiane po kodeksie klauzule generalne już wtedy budziły obawy przed skutkami ich nadużywania ze szkodą dla ekonomicznie i społecznie słabszych jednostek ${ }^{49}$.

niu Prawa prywatnego austriackiego z 1911 roku kładł nacisk na te sformułowania art. 1, które świadczyły, że ustawodawcy chodziło tylko o sytuację istnienia luki w prawie; poza tymi przypadkami wykluczano przywłaszczenie przez sędziego funkcji prawodawcy. Po I wojnie Till w studium O stanowisku sędziego w odrodzonej Polsce, „Kwartalnik Prawa Cywilnego i Karnego”, 1918, powtarzał tezę, że art. 1 ZGB nie stanowi zagrożenia dla pewności i stabilności prawa, pod warunkiem, że sędzia nie będzie świadomie wyrokował contra legem. K. Sójka-Zielińska, Ernest Till (1846-1926), „Kwartalnik Prawa Prywatnego” 1997, z. 3, s. 415, 42.

${ }^{48} \mathrm{~K}$. Sójka-Zielińska, Zasada stuszności wobec teoretycznych założeń kodyfikacyjnych XIX wieku. P i P, 1974, z. 2, s. 30 n.

49 Jak pisał Leon Petrażycki, ,Szczególnie szkodliwe jest nadanie ogromnego znaczenia uznaniu sędziego i używanie w ustawie takich wyrażeń, które z istoty swojej czynią koniecznym uznanie 
Ideologia neokantyzmu stała się natomiast ważnym punktem oparcia dla Eugena Hubera w pracach nad kodyfikacją prawa cywilnego. Ze Stammlerem łączyła go nie tylko osobista przyjaźń z czasów profesury w Halle, ale i wspólnota ideałów (zadedykował nawet niemieckiemu koledze swą rozprawę pt. Soziale Rechtsgewinnung). Wyrazem ideowej bliskości z kierunkami odrodzonego prawa natury było wprowadzenie przez Hubera ogólnego, odnoszącego się do wszystkich gałęzi prawa prywatnego, zakazu nadużycia prawa podmiotowego. Według art. 2 tytułu wstępnego ZGB, „każdy ma wykonywać swoje prawa i wypelniać obowiązki zgodnie z regułami dobrej wiary, a wyraźne nadużycie prawa nie będzie prawnie chronione". Wobec pogłębiających się konfliktów społecznych i drastycznej nierówności materialnej, grożącej rewolucyjnym przewrotem, wprowadzenie do kodeksu zasad etyki otwierało przed wymiarem sprawiedliwości możność łagodzenia skutków tych procesów w duchu solidaryzmu społecznego.

Na czele zadań, jakie stawiał Huber w pracach nad kodyfikacją cywilną było, jak pamiętamy, doprowadzenie do kompromisu między kantonami romańskimi i niemieckimi. Wśród różnych przyczyn konfliktu były także spory ideologiczne między kantonami wywodzącymi się z kręgu panowania Code civil a kantonami niemieckimi, przedstawiane jako starcie między romańskim indywidualizmem a germańskim etatyzmem. Chodziło więc o pogodzenie przywiązania kręgów społecznych wyrosłych w tradycjach kodyfikacji napoleońskiej do idei indywidualizmu z - uwzględniającą realia społeczno-gospodarcze i polityczne tej epoki - idea socjalizacji prawa. Huberowi uda się ostatecznie te sprzeczne tendencje i konflikty interesów rozwiązać poprzez wyjście pośrednie, określane w literaturze mianem indywidualizmu społecznego ${ }^{50}$.

Ogólnie biorąc, idea socjalizacji prawa prywatnego w ZGB wyrażała się m.in. zaangażowaniem autorytetu państwa $\mathrm{w}$ ochronę podmiotów powszechnie uznawanych za strony ekonomicznie i społecznie słabsze drogą pewnej relatywizacji praw podmiotowych, np. poprzez wspomniany już generalny zakaz ich nadużywania, a nawet dopuszczalne w sytuacjach wyjatkowych, uzasadnionych ogromem materialnych dysproporcji w społeczeństwie, stosowanie zasady nierówności prawa przez nakładanie na strony ekonomicznie silniejsze szczególnych obowiązków ${ }^{51}$.

sędziego. Zwłaszcza dla niezamożnych klas ludności i ludzi zależnych, np. służby, robotników, takie paragrafy to prawdziwe utrapienie [...] przekształcają one sędziego-stróża prawa w urzędnika rządzącego się według własnego uznania..." Wstęp do nauki polityki prawa, Warszawa 1968 s. $187 \mathrm{n}$.

${ }^{50}$ P. Liver, Das Zivilgesetzbuch - geschiebenes Rechtswissen des Schweizervolkes, w: Privatechtliche Abhandlungen, 1. c., s. 127; szerzej o tym B. Dölemeyer, Handbuch, 1. c., s. 1990.

${ }^{51}$ P. Caroni, Gesetz, s. 81 n. Przezwyciężanie antynomii zawartej w samym pojęciu indywidualizmu socjalnego i wynikającej stąd sprzeczności między interesem indywidualnym a dobrem społecznym wymagało aktywnego wkraczania państwa w sferę stosunków prywatnoprawnych. 
Wątki rozwiązań w duchu kompromisu między indywidualizmem a społecznym solidaryzmem występowały we wszystkich częściach szwajcarskiej kodyfikacji.

W prawie osobowym tytuł dotyczący osób fizycznych został oparty na zasadach powszechności i równości praw cywilnych. Według art. 11 ZGB, „każda osoba ma prawa cywilne; w konsekwencji każdy ma, w granicach ustawy, równą zdolność bycia podmiotem praw i obowiązków". W myśl pierwotnego brzmienia art. 27 ZGB nikt nie mógł pozbywać się w ogóle lub częściowo zdolności prawnej i zdolności do działań prawnych; jak również swej wolności ani jej ograniczać w stopniu naruszającym prawo i dobre obyczaje.

Natomiast tytuł dotyczący osób prawnych nawiązywał do dawnych tradycji wspólnotowych, dopuszczając w szerokiej mierze różne formy zrzeszania się obywateli oraz ułatwienia w powstawaniu stowarzyszeń (Gesellschaften) i fundacji (Stiftungen).

W pierwotnej wersji księgi o prawie familijnym znajdujemy stosunkowo najwięcej pochodzących z dawnych praw zwyczajowych - ale i występujących w kodyfikacjach prawnonaturalnych - ograniczeń zasady powszechności i równości praw podmiotowych. Stąd też ten dział prawa został poddany po II wojnie światowej gruntownym reformom z lat 70. i 80. XX wieku ${ }^{52}$. Owe ograniczenia dotyczyły przede wszystkim statusu kobiety w związku małżeńskim. Według art. $160 \mathrm{w}$ pierwotnym brzmieniu, „Mąż jest głową rodziny; on ustala miejsce jej zamieszkania, ma obowiązek troski o utrzymanie żony i dzieci”, żona mogła podejmować pracę zawodową tylko za zgodą męża (art. 167). Przewaga męża występowała $\mathrm{w}$ prawie majątkowym małżeńskim, a także w stosunkach prawnych między rodzicami i dziećmi ${ }^{53}$. Innym przejawem nierówności były ograniczenia dotyczące sytuacji prawnej dzieci pozamałżeńskich (art. 302 i n.) $)^{54}$.

Pogłębiał się proces tzw. publicyzacji prawa prywatnego, który, jak wiemy, spotkał się z konstatacją Georges'a Riperta tout devient droit public! Kodyfikacja szwajcarska, która stała na gruncie formalnej równości wobec prawa, ustalała w sposób niepisany dopuszczalne granice interwencjonizmu, a z biegiem czasu skutecznie neutralizowała socjalizujące ambicje prawa publicznego (tamże, s. 85)

${ }^{52}$ Pierwszą większą nowelizację prawa rodzinnego wprowadzono ustawą z 25 VI 1976 r. (z mocą obowiązującą od 1978 r.). Kolejna obszerna nowelizacja ZGB w obszarze prawa rodzinnego i związanych z nim przepisów prawa spadkowego nastąpiła przyjętą w drodze referendum ustawą z 5 X 1984 r., która weszła w życie 1 stycznia 1988 r. Jej omówienie daje A. Dyoniak, Nowelizacja szwajcarskiego kodeksu cywilnego. (Problemy prawa spadkowego i rodzinnego), „Nowe Prawo” 1990, z. 1-3, s. 96 n.

${ }^{53} \mathrm{~W}$ myśl art. 274 w sprawowaniu władzy rodzicielskiej decydujący głos należał do ojca. Równouprawnienie obojga małżonków w sprawowaniu władzy rodzicielskiej nastąiło dopiero w wyniku reformy z roku 1976. Wg nowego brzmienia art. 297, „, w czasie trwania małżeństwa ojciec i matka sprawują wspólnie władzę rodzicielską".

${ }^{54}$ Zrównanie w prawach wszystkich dzieci, tj. również pozamałżeńskich i adoptowanych, nastapiło na mocy nowelizacji z 1976 r. 
Również w prawie spadkowym występowały ograniczenia w prawach do dziedziczenia pewnych kategorii spadkobierców, tj. współmałżonka oraz rodziców naturalnych i dzieci pozamałżeńskich. Ograniczenia te zostały uchylone w ramach nowelizacji z 1984 roku $^{55}$.

W księdze IV o prawie rzeczowym (Das Sachenrecht, Les droits réels) najsilniej zaznaczyły się - podobnie jak w BGB - idee socjalizacji prawa cywilnego. W czasach powszechnego odwrotu do liberalizmu, w obliczu kryzysów ekonomicznych i pogłębiających się antagonizmów społecznych politycy i ekonomiści szukali ratunku m.in. w podporządkowaniu egoistycznych interesów właścicieli interesom ogółu, co wyrażano hasłami uspołecznienia własności. Reformatorzy z obozu germanistów powoływali się przy tym na tradycje średniowiecza, kiedy prawo własności jednostki było z samej istoty najściślej powiązane z interesami szerszych wspólnot społecznych, a w samym rozumieniu własności były zawarte ograniczenia właściciela i jego obowiązki wobec rodziny, sąsiadów, gmin, czy też - jak u św. Tomasza - wobec wszystkich potrzebujących $^{56}$.

W kodeksie szwajcarskim koncepcja własności została oparta na praktyce funkcjonowania średniowiecznych wspólnot, w których jednostka była całkowicie w struktury społeczne wtopiona. Już w samej definicji prawa własności były zawarte ograniczenia jej wykonywania: „Właściciel rzeczy ma prawo nią swobodnie dysponować w granicach prawa" (art. 641 ZGB). Przepisom dotyczącym własności ziemskiej (Grundeigentum, propriété foncière) towarzyszyły liczne drobiazgowe regulacje z dziedziny stosunków sąsiedzkich dotyczące ograniczeń właścicieli nieruchomości (art. 667-701), zresztą powitane $\mathrm{z}$ aprobata $\mathrm{w}$ kantonach konserwatywnych ${ }^{57}$.

Charakterystycznym nawiązaniem do tradycji średniowiecznego kolektywizmu było uregulowanie w ZGB (art. 652 n.) - instytucji własności wspólnej (Gesammteigentum, propriété commune), w której udział każdego z członków wspólnoty rozciaggał się na cały przedmiot własności.

Również konstrukcja posiadania nieruchomości - podobnie jak w BGB - nawiązywała do średniowiecznej, znanej prawom szczepowym germańskim instytucji gewere, władania polegającego jedynie na pobieraniu pożytków

\footnotetext{
${ }^{55}$ Nowelizacja zmierzała m.in. do wzmocnienia pozycji prawnej pozostałego przy życiu małżonka, ograniczenia kręgu osób uprawnionych do dziedziczenia oraz zwiększenia części spadku, którą spadkobierca mógł swobodnie dysponować. A. Dyoniak, 1. c., s. 105 n.

${ }^{56}$ Szerzej o poglądach germanistów na charakter prawa własności K. Kroeschell, Zur Lehre vom germanistischen Eigentumsbegriff, w: Rechtshistorische Studien, Hans Thieme zum 70. Geburtstag, 1977, s. 34 n. vide też W. Wilhelm, Private Freiheit und gesellschaftliche Grenzen des Eigentums in der Theorie des Pandentenwissenschaft, Wissenschaft und Kodifikation des Privatrechts im 19. Jahrhundert, Bd. IV, Frankfurt/M 1979, s. 29 n.

${ }^{57}$ Autor podręcznika szwajcarskiego prawa cywilnego w języku francuskim, Virgile Rossel, okrzyknął któreś z tych ograniczeń jako „wielką, ale zbawienną, innowację dla naszych zachodnich kantonów!” P. Liver, o. c., s. 128.
} 
z nieruchomości. Do kategorii posiadaczy zaliczano więc użytkowników, dzierżawców itp., dopuszczając tym samym jednoczesne posiadanie nieruchomości przez kilka podmiotów (w średniowieczu zwane mehrfache gewere) ${ }^{58}$. Według art. 919 ZGB, ,ten, który faktycznie włada rzeczą, ma jej posiadanie”. Zawarto tu tylko jeden element rzymskiej definicji posiadania - faktycznego władztwa (corpus); zabrakło natomiast drugiego elementu - woli władania rzeczą jako własną (animus), co wynikało z ewolucji poglądów XIX-wiecznej doktryny niemieckiej na istotę i funkcje posiadania ${ }^{59}$.

Dzień, w którym kodeks cywilny został przez parlament j e d n o m y ś ln i e (!) uchwalony, oznaczał dla jego twórcy, Eugena Hubera, uwieńczenie długotrwałych zabiegów o zakończenie konfliktów między kantonami z kręgu kultury prawnej Code civil i kantonami obszarów niemieckojęzycznych m.in. przez pogodzenie prawnonaturalnych idei indywidualizmu z sięgającym tradycji średniowiecza duchem społecznym prawa, które zrealizował w kompromisowej formule indywidualizmu socjalnego. Huber osiagnął jeszcze inny cel, zarysowany w komentarzu do projektu wstępnego. Było nim opracowanie kodeksu, który byłby czytany i rozumiany przez wszystkie kręgi społeczeństwa. Ustawa ta miała wyrobić powszechne przekonanie, że jest odzwierciedleniem najlepszych wzorców obyczajowych i poglądów prawnych ludności. Jak pisał w komentarzu, ,każdy rozumny człowiek, który ją czyta i myśli o swych potrzebach, musi mieć przeświadczenie, że ukazuje ona spisaną świadomość prawną Szwajcarów (das geschriebene Rechtswissen des Schweizervolkes)"60.

X. Ukazanie się ZGB, który zamykał poczet wielkich kodyfikacji cywilnych Europy, wzbudziło wielkie zainteresowanie w kręgach europejskiej cywilistyki, zwłaszcza w doktrynie francuskiej oraz w publicystyce niemieckiej, zdominowanej ówcześnie przez zagorzałych krytyków BGB, którzy przemyśliwali nawet nad jego zastąpieniem przez kodyfikację szwajcarską.

Kodeks miał też szczególne znaczenie dla prawoznawstwa porównawczego, służąc jako wzorzec, „model idealny” dokonań tej gałęzi wiedzy na polu stanowienia prawa. Huber, ówcześnie zaliczany do najwybitniejszych znawców komparatystyki prawniczej, budował przecież swe dzieło na ogromnym materiale porównawczym, obejmującym nie tylko wielce zróżnicowane prawa poszczególnych kantonów, ale systemy prawa prywatnego różnych państw

${ }^{58}$ K. Koranyi, Powszechna historia państwa i prawa, t. II, Warszawa 1963, s. 178.

${ }^{59}$ Decydujące znaczenie miało tu zwycięstwo nowego kierunku studiów nad posiadaniem Rudolfa Iheringa nad dawnymi romanistycznymi koncepcjami v. Savigny’ego. K. Sójka-Zielińska, Wielkie kodyfikacje, s. $321 \mathrm{n}$.

${ }^{60}$ P. Liver, Das Zivilgesetzbuch-geschribenes Rechtsgewissen des Schweizervolkes, w: Privatrechtliche Abhandlungen, o. c., s. 132. Najbliższy współpracownik Hubera w komisjach parlamentarnych, Virgile Rossel, wyraził się kiedyś, że jak o Kodeksie Napoleona mówi się jako o raison écrite, tak kodeks szwajcarski stanowi conscience écrite du peuple suisse (tamże, s. 123). 
kontynentalnej Europy. Z kolei sam kodeks szwajcarski był obiektem zainteresowań prawoznawstwa porównawczego pod kątem jego wpływów w krajach europejskich podejmujących reformy idące z duchem czasu. ZGB stanowił ówcześnie wzór nowoczesnej kodyfikacji, a elastyczność sformułowań umożliwiała dostosowywanie przepisów do zmieniających się społeczno-gospodarczych uwarunkowań bez konieczności podważania podstawowych zasad porządku prawnego ${ }^{61}$.

Wśród krajów, które czerpały wzory z kodyfikacji szwajcarskiej, wymienia się m.in. Liechtenstein, który w pracach nad częściową kodyfikacją w latach 20. recypował przepisy ZGB o prawie rzeczowym (1922), o prawie osobowym wraz z prawem o stowarzyszeniach (1926) i prawie zobowiązań. W Austrii wpływ ZGB zaznaczył się w nowelizacjach ABGB z lat 1914-1916, a na Węgrzech - w projekcie kodeksu cywilnego z 1915 roku. Wśród kodyfikacji cywilnych nawiązujących do ZGB wymienia się także kodeks grecki z 1940 roku, włoski z 1942 roku oraz francusko-włoski projekt kodeksu zobowiązań z 1927 roku.

Najbardziej spektakularnym wydarzeniem w annałach komparatystyki prawniczej była recepcja globalna kodeksu szwajcarskiego w Turcji, przeprowadzona przez wielkiego reformatora ustroju politycznego i prawa tureckiego, prezydenta Kemala Atatürka (1881-1938).

Po zakończeniu I wojny światowej na mocy traktatu pokojowego w Lozannie (1923) zwycięskie mocarstwa wymogły na władzach nowo powstałej na gruzach imperium osmańskiego Republiki Tureckiej radykalną modernizację m.in. ustroju sądownictwa i laicyzację prawa prywatnego. Na tej podstawie Wielkie Zgromadzenie Narodowe uchwaliło 4.10.1926 roku turecki kodeks cywilny i turecki kodeks zobowiązań, które stanowiły luźny przekład francuskich wydań ZGB oraz prawa zobowiązań (OR). Wybór kodeksu był podobno dziełem przypadku. Jeszcze przed I wojną wielu Turków studiowało na uniwersytetach szwajcarskich. Jednym z absolwentów był późniejszy minister sprawiedliwości, który brał udział w redagowaniu francuskiej wersji językowej kodeksu. Są jednak opinie, że decydującym czynnikiem były zalety formalne ZGB, zwięzłość, jasność, dalekowzroczność, a także fakt, że język francuski był znacznie bardziej w społeczeństwie rozpowszechniony niż niemiecki ${ }^{62}$. W wyniku rewolucyjnej zmiany, jaką była laicyzacja prawa cywilnego, Turcja wyszła ostatecznie z kręgu prawnego osmańsko-islamskiego. Wprawdzie w praktyce stosowania kodeksu nie obyło się bez trudności, a niektóre przepisy np. prawa osobowego i małżeńskiego ZGB pozostały martwą literą, jednak na

${ }^{61}$ A. Schnitzer, Vergleichende Rechtslehre. B I Basel 1961 wyd. II, s. 237 n. ZGB stanowił też punkt odniesienia dla badaczy międzynarodowego prawa prywatnego. Przykładem może być dwutomowe dzieło A. Schnitzera Handbuch des internationalen Privatrechts unter besonderen Berücksichtigung der Schweizerischen Gesetzgebung und Rechtsprechung, Basel 1944.

${ }^{62}$ K. Zweigert - H. Kötz, Einführung, s. 207 n. 
fundamentach kodyfikacji szwajcarskiej prawo cywilne Turcji rozwinęło się w samodzielny system prawny. Sam fakt udanej recepcji prawa cywilnego in toto na całkowicie odrębny kulturowo i etnicznie obszar stanowił dla komparatystów argument przeciw tezom szkoły historycznej o organicznym, wypływającym $z$ ducha narodu, rozwoju prawa ${ }^{63}$.

Kodyfikacja szwajcarska zyskała wysokie uznanie w cywilistyce polskiej II Rzeczypospolitej, szczególnie ze względu na jej walory formalne ${ }^{64}$. Program unifikacji i kodyfikacji prawa cywilnego, uważany za najcięższy obowiązek legislacyjny, jaki stanął przed którymkolwiek z państw powojennej Europy ${ }^{65}$, bo polegający na zastapieniu obcych systemów prawnych nowym od podstaw własnym ustawodawstwem, wiązał się z trudnościami przezwyciężania lokalnych partykularyzmów podobnymi do zmagań, jakie twórcy ogólnoszwajcarskej kodyfikacji toczyli z obrońcami niezależności prawnej kantonów.

Największy wpływ ZGB zaznaczył się w pracach nad projektem prawa zobowiązań. Do kodyfikacji szwajcarskiej nawiązywała sama koncepcja ujęcia prawa obligacyjnego w odrębnym kodeksie. Ale zasadniczym powodem sięgania do prawa szwajcarskiego było to, że Obligationenrecht łączyło w sobie rozwiązania pochodzące $\mathrm{z}$ różnych systemów prawnych. W warunkach istnienia mozaiki prawnej odziedziczonej po czasach zaborów rozwiązania szwajcarskie stanowiły wzorzec dla polskiego ustawodawcy ${ }^{66}$.

$* * *$

Zamiast zakończenia warto w tym miejscu przywołać - za podręcznikami prawoznawstwa porównawczego - refleksję Eugena Hubera na temat przyszłości prawodawstwa: „Jeśli kiedyś doszłoby do opracowania kodyfikacji europejskiej (europäische Kodifikation), znaczący udział w tym dziele powinno mieć prawo szwajcarskie".

${ }^{63}$ A. Schnitzer, Vergleichende Rechtslehre, 1. c., s. 353.

${ }^{64}$ Ogólną ocenę ZGB daje L. Górnicki, O pojęciu i znaczeniu wielkich kodeksów cywilnych w zwiazku z ksiaqżkq Katarzyny Sójki-Zielińskiej ,,Wielkie kodyfikacje cywilne”. „Kwartalnik Prawa Prywatnego" 2012, z. 1, s. 51-81. Opinie polskich cywilistów o ZGB przytacza A.M. Falkowska, Szwajcarski kodeks zobowiazań w pracach Komisji Kodyfikacyjnej Rzeczypospolitej Polskiej w okresie dwudziestolecia międzywojennego. „Studia Iuridica Toruniensia” t., IV, Torun 2008, s. $57 \mathrm{n}$.

${ }^{65}$ F.X. Fierich, Unifikacja ustawodawstwa, w: Dziesięciolecie Polski odrodzonej. Księga Pamiatkowa 1918-1928. Kraków-Warszawa 1928, s. 263.

${ }^{66}$ A. Falkowska, o. c., s. 59; szczegółowe przykłady powoływania się na ZGB w pracach nad kodeksem zobowiązań ukazuje L. Górnicki, Prawo cywilne w pracach Komisji Kodyfikacyjnej Rzeczypospolitej Polskiej w latach 1919-1939, Wrocław 2000, s. 411 n. Tam także wzmianki o oddziaływaniach kodyfikacji szwajcarskiej na projekty prawa małżeńskiego, rzeczowego i spadkowego. 


\title{
A HUNDRED YEARS OF THE SWISS CIVIL CODE
}

\author{
S u m m a r y
}

The Swiss Civil Code (Schweizerisches Zivilgesetzbuch - ZGB) came into being on 1 January 1912 culminating the series of so called great civil codifications of continental Europe. The vast experience in the codification work within the Roman legal culture allowed the editors of the ZGB, and its author, Eugen Huber in particular, to create a truly original work that perfectly combined long legal traditions of individual Swiss cantons with the requirements of contemporary expectations, the ideas of individualism with those of social solidarity, the liberal slogans with the policy of interventionism, and the letter of law with the principles of equity and the canons of ethics.

The staring point for the Swiss Civil Code was a draft authored by W. Munziger, which referred to the Zurich Code Civil, the German commercial code, the Austrian ABGB of 1861 and the Dresdener law of obligations of 1866. Another important stage was the initiative of the Swiss Juristenverein which in 1884 proposed a comparative study of all cantonal private law systems. The results of that study were to serve as a basis for the future nationwide unification of the legal system. Between 1893 and 1898 Eugen Huber developed three preliminary drafts, covering family law, succession law and rights in property. In 1900 they were published as a government project and put forward for a public discussion carried out by a 31-member expert group, with wide participation of individual citizens and interest groups. Eventually, on 10 December, the project was unanimously adopted as Schweizerisches Zivilgesetzbuch, Codice civile svizzero (ZGB) to come into force and be binding as of 1 January 1912.

Among the many states drat drew on the Swiss Civil Code when drafting their own codes were Lichtenstein, Austria, Hungary, Greece, Italy and Turkey. In the latter, the ZGB was adopted as part of the reforms under Kamal Atatürk. The Swiss codification was highly valued by the civil lawyers in the Second Polish Republic.

\section{LE CENTENAIRE DU CODE CIVIL SUISSE}

\section{R é s u m é}

Le Code civil suisse (Schweizerisches Zivilgesetzbuch - ZGB) de 1912 tient une place remarquable parmi les grands codifications civiles de l'Europe continentale. La riche expérience acquise au cours des travaux préparatoires sur les vingt-trois codes civils cantonaux permettait à son auteur, Eugène Huber de créer une oeuvre entièrement original, ainsi qu'y mettre d'accord la tradition des anciens droits coutumiers avec l'orde juridique moderne; les idées de l'individualisme avec les mots d'ordre de solidarité sociale; les principes du libéralisme économique avec 
la politique d'étatisme; la lettre de la loi - avec la méthode de l'interprétation en esprit de l'équité et de la morale.

La naissance de la codification est un processus long et difficile, lié à la situation géopolitique du pays, implanté au coeur de l'Europe, au régime politique confédératif et particularisme juridique, à l'évolution des idées lesquelles s'infiltrent rapidement en Suisse pour s'y développer au siècle des Lumières et à l'époque de la Révolution française. Les travaux de codification ont duré d'ailleurs depuis la moitié de XIX ${ }^{\mathrm{e}}$ siècle. Le point de départ est le projet de $\mathrm{W}$. Munzinger qui fait référence au code civil de $\mathrm{Zu}$ rich, au Code civil, à l'ABGB, au code du commerce allemand de 1861 ainsi qu'au projet de Dresde de 1866 portant sur les obligations. L'étape importante des aspirations vers l'atteinte d'une unité juridique dans la Fédération s'ouvre au moment où apparait l'initiative de Juristenverein suisse qui en 1884 fait la demande d'entamer les études comparatives de l'ensembles des règimes du droit privé cantonaux, envisageant déjà la future unification nationale. Dans les années 1893-1898, Eugène Huber élabore trois projets partiels et préliminaires portant sur le droit de la famille, le droit successoral et le droit réel. Les projets sont publiés en 1900 comme un projet gouvernemental soumis au débat. Ce dernier, animé par une commission composée de 31 experts, se déroule avec une large participation des citoyens et des groupes d'intérêts. Ainsi, les rédacteurs souhaitent-ils éviter de reproduire la situation survenue lors des débats menés au sujet du $2^{\text {ème }}$ projet du BGB, laquelle a impacté d'ailleurs leur déroulement.

Après une longue discussion dans les chambres parlementaires, le projet est transmis à l'Assemblée fédérale où le 10 décembre 1907 il est adopté à l'unanimité sous le nom de Schweizerisches Zivilgesetzbuch, ZGB en vigueur à partir du $1^{\text {er }}$ janvier 1912. Les principes générales du Code sont présentés par Huber dans son Commentaire (Erläuterungen), ce dernier ayant été joint au projet officiel du gouvernement.

Parmi les pays qui se sont inspirés et ont pris l'exemple sur la codification suisse, nous pouvons énumérer, entre autres, le Liechtenstein, l'Autriche, la Hongrie, la Grèce, l'Italie et la Turquie où le ZGB est repris dans le cadre des réformes réalisées par Kemal Atatürk. La codification suisse gagne de la notorité dans la science du droit civil polonais sous la $2^{\mathrm{e}}$ République, notamment pour ses valeurs formelles. 